\title{
The Political Economy of Global Agriculture: Effects on Agriculture, Farmers, Consumers and Economic Growth
}

\author{
M.B. Dastagiri \\ Principal Scientist, ICAR-National Academy of Agricultural Research \\ Management, Rajendranagar, Hyderabad, India \\ Anjani Sneha Vajrala \\ Junior Research Fellow, ICAR-NAARM, Rajendranagar, Hyderabad, India
}

Doi: 10.19044/esj.2018.v14n4p193 URL:http://dx.doi.org/10.19044/esj.2018.v14n4p193

\begin{abstract}
International political economy deals with mutual interaction of international politics and international economics. The ever-changing political scenarios, be it right-wing or left-wing, agriculture in particular has been neglected. The main focus of the paper is to study the effects of political economy on agriculture, farmers, consumer welfare and economic growth. The data on indicators collected from FAO, World Bank, IMF, UNDES, WEF, OECD, CGIAR reports. The growth rates, Agricultural Orientation Index (AOI) and statistical-analysis estimated. Globally, political and economic systems, international governments like World Bank, IMF and WTO's attitude towards agriculture is poor. Agriculture must be brought on global political agenda for sustainable food security, economic growth and development and to achieve Millennium Development Goals (MDG's). The protection of producers and consumers is being based on political will of governments. The study concludes for developing countries, stimulus package is required for the development of agriculture. The political economy of AOI indicates that the countries which have more than 1 will spend more budget in budget allocation towards agriculture. The study found that, clearly agriculture globally is not on the priority list for the local central governments in allocating their budgets towards agriculture. The study suggests that, economic minded politicians and political minded economists who has knowledge of social, political and economic systems are required in efficient economic system of agriculture.
\end{abstract}

Keywords: Global agriculture, Political economy, International institutions, Farmers, Consumers 


\section{Introduction:}

International politicians tend to neglect economic dimensions while dealing with international relationships and international economists tend to neglect political dimensions in dealing with international economy. Benefitcost analysis is a tool devised by economists. Economists think in terms of opportunity costs and incentives; lawyers think in terms of rules and penalties and of defeating their adversary (Schultze, 1977; Rhoads, 1985). Politicians determine the optimal policy by maximizing their own utility which is of political contribution called growth or social welfare and votes. They also focus on political economics of fiscal policy, macro economy and the role of constitution. The role of government in agriculture in agricultural marketplace each year is in each step from the farm to the market, there is a framework of national, state, and local government policies. Government may influence what a farmer grows, where a farm is located, how products are transported and processed, how a commodity is traded, and the price the farmer might receive (Iowa Public Television, 2017).

International political economy studies problems that arise from or are affected by the interaction of international politics, international economics, and different social systems (e.g., capitalism and socialism) and societal groups (e.g., farmers at the local level, immigrants in a region, the poor who exist transnationally in all countries) (Encyclopedia Britanica, 2017). Models need to incorporate sufficiently complex interactions between ideology, economic structure, and protection to understand better how this web of interactions affects agricultural and food policies. Consider, for example, food policies of the most extreme left-wing regimes. Communist dictators such as Stalin in Russia, Mao in China, and Hoxha in Albania all heavily taxed agriculture, while farmers were subsidized under the Communist regimes of Brezhnev in the Soviet Union and in most East European Communist countries in the 1970s and 1980s (Johan F.M. Swinnen, 2010).

The political institution variables require further improvement. For example, Swinnen, Banerjee, and de Gorter (2001) find how some of the changes in voting rules in Belgium had effects on agricultural protection, while others had no effect. In particular, those changes in electoral rules which disproportionately benefited people involved in agriculture (such as extending voting rights to small farmers and tenants in the early twentieth century) induced an increase in agricultural protection, while electoral changes (such as extending voting rights to women) did not affect agricultural protection. Rather, they increased voting rights both of those in favor of and of those against protection.

An area where substantial improvements could be made is in analyzing the impact of international organizations and international trade agreements on agricultural policy distortions. While this issue has received considerable 
attention over the past decade, for example, the URAA effects, the establishment of the WTO, NAFTA, EU enlargement, etc., there has been little econometric work on this issue. It seems to agree that while the URAA may have constrained the growth of agricultural protection, it has done little to reduce it, at least in the countries that were members of the General Agreement on Tariffs and Trade (GATT) during the trade negotiations (Anania et al. 2004). Bagwell and Staiger (2002) and Dutt and Mitra (2007) derive hypotheses that countries with a comparative advantage in agriculture who join the WTO will exhibit a larger fall in agricultural protection levels.

Many (agricultural) political econometric models effectively focus on producers (farmers), consumers and taxpayers. Some recent models have tried to include politicians' preferences by including an "ideology" variable. However, this needs to be improved in order to correctly measure influences. Similarly, the role of other bureaucratic organizations, such as the European Commission, is mostly not captured, although they may play an important role (Prendergast,2007). Political entrepreneurs may also play a role in organizing interest groups and making their preferences more influential. For example, politicians played a key role in organizing farmers in rural Europe in the late nineteenth and early twentieth centuries as they tried to set up farm organizations that were closely associated with certain political parties. More recently, some (politically "savvy") African leaders have been using (rural) interests either to ensure their political survival, such as Mugabe in Zimbabwe, or their rise to power, such as in the post-Mao political struggle in China when the reformers around Deng Xiaoping took over control of the Communist Party, aided by the success of the property rights reforms (Rozelle and Swinnen 2009).

The financial (institutional/political) crises affecting the global setting, for example, the financial crises in Latin America in the 1980s and in Asia in the 1990s, the liberalization reforms after the political changes in the Soviet Union in the 1990s, and the structural adjustment programs in Africa in the 1980/90s. With regard to political institutions, while the importance of political systems for policy, and thus agricultural policy distortions, has long been emphasized, for example as in the seminal work by Buchanan and Tullock (1962), the past decade and a half has witnessed a growing set of studies that analyze the impact of political regimes and ideology on policymaking. Persson and Tabellini $(2002 ; 2003)$ analyzed the relationship between electoral systems and economic policy. To relate some of these more general insights to agricultural policy-making, consider the political regime, the "constitutional choice," in the framework of providing the degree of "insulation" afforded to policy-makers (Aghion, Alesina and Trebbi 2004).

Several empirical studies do find an impact of political institutions on trade and agricultural policy. For example, Banerji and Ghanem (1997) and 
Milner and Kubota (2005) find that authoritarian regimes do have higher trade protection and greater labor market distortions. In a related approach, Masters and McMillan (2000) and McMillan (2001) find that governments that have a lower discount rate (that is, those that are less likely to lose power in the future, which presumably includes more autocratic regimes) are less likely to tax agricultural exports in Africa. Olper and Raimondi (2009) find that, within democratic regimes, agriculture is significantly more protected under proportional electoral rule than under majoritarian. However, they do not find a difference between presidential and parliamentary electoral systems ideology. An interesting approach to disentangling some of the problems regarding the interactions between political institutions and preferences of autocratic rules is proposed by Dutt and Mitra (2005). These authors focus on the impact of ideology and allow the ideology variable to interact with an indicator of the structure of the economy, that is, its resource endowment, as well as an indicator for political liberties, to measure the conditional impact of ideology. Interestingly, they find that the more left-wing a government is, that is, it attaches higher weight to the welfare of workers/labor, the more protectionist it is in the case of capital-abundant countries, but the less protectionist it is in the case of capital-scare countries.

Swinnen (forthcoming 2009), who finds that right-wing governments in Europe, such as those dominated by Catholic parties and conservative parties, as well as the Nazi party in Germany (1933-1945), have tended to support farm interests and increase protection. Swinnen and Anderson (2010) gives, a review of the most dramatic changes in agricultural policy distortions that have occurred in recent decades reveals that these have been triggered by "external changes." For example, it is well known that budgetary problems played an important role in stimulating agricultural policy liberalization in Sweden and New Zealand in the 1980s. Similarly, regime changes in China, Eastern Europe and the former Soviet Union triggered important changes in their agricultural policies. In fact, one could even argue that the objective of these governments was not to change agricultural policy per se, but that overall changes implied a change in agricultural policy as well. Blanchard and Willmann (2007) show, with a dynamic political economy model, that in a democracy there may be two steady states: one protectionist and one liberal.

Global agriculture needs a 'profound transformation' to fight climate change and protect food security, hunger, poverty. In response to this challenge, the New Vision for Agriculture calls for a new approach. The new approach is global leaders have aligned around the New Vision for Agriculture. Regional and national leaders have adopted the vision as their own, catalysing action-oriented partnerships in Asia, Africa and Latin America. (Dastagiri, 2017). Agriculture in the 21st century has multiple challenges. In the recent political international developments, globally, 
agriculture seems is back on the development agenda, seen as a key to spurring growth and reducing poverty, and as a key route to meeting the Millennium Development Goals (FAO, 2012). Experts and the public alike seem to alternate between pessimism and optimism, anxiety and complacency, about the world food situation and outlook. For the past few decades, the rate of growth in world food production in both developed and developing countries has exceeded the population growth rate. During the 1970s and 1980s the food situation improved tremendously (Mrityunjay and Singh, 2008). But by the 1980 s and 1990s the increasing scarcity of land and water resources, environmental degradation, and loss of biodiversity had begun to limit the expansion of food production in both developed and developing countries (Dastagiri, 1998).

World Watch Institute (2004) reports that increases in food production, per hectare of land, have not kept pace with increases in population, and the planet has virtually no more arable land or fresh water to spare. FAO (2011) emphasizes agricultural investment is essential to promoting agricultural growth, reducing poverty and hunger, and promoting environmental sustainability. Reports on global food security in 2011 by the IFPRI (2011) and other reports of the FAO (2012), the World Bank (2011), and the International Fund for Agricultural Development (2011) all highlighted the need for governments to ensure responsible investment in agriculture. Global food security - or, in more traditional terminology, world hunger- remains a serious concern (Valentin, 2011). However, even at the global level, current food supplies are sufficient to nourish the world population (Valentin, 2011). Food insecurity, therefore, results from uneven distribution. In the coming decades, calorific production is projected to further outpace population growth (Valentin, 2011). Global food crises are turning out to be far too frequent to be dismissed any longer as a freakish phenomenon. A spike in the prices of agricultural commodities is again looming, threatening a repetition of the 2007-2008 global food crisis when international prices skyrocketed to their highest in 30 years (Caliber, 2012).

The International Monetary Fund (IMF)'s food price index rose by over 80 per cent between the start of 2007 and mid-2008 (Subramaniam, 2012). Severe drought in the United States, flooding in several parts of Europe, a massive shortfall of rain in Africa and India are feared to lead to huge loss of output and a scramble for markets and supplies (Subramaniam, 2012). As in many other parts of the world, soaring food prices during the period 2007/08 had major impacts on the countries of Southeast Asia. It is hardly surprising that the use of cost-benefit analysis, quantitative risk assessment, and similar analytic tools generates substantial political controversy in the United States. The risks, costs, and benefits under scrutiny are usually difficult to estimate with precision. (Calabresi and Bobbitt, 1978). 
Human beings in general and elected officials in particular find it difficult to admit that the policies they support leave some innocent people at risk, especially when that risk is potentially lethal (R. Shep Melnick)

Most regulatory agencies are internally diverse, numbering economists and political executives, as well as lawyers, engineers, and scientists, among their staffs. Political executives must take responsibility for the consequences of agency decisions - economic as well as environmental. Agency economists spend a good deal of their time estimating the economic consequences of regulatory decisions and responding to arguments put forth by economists outside the agency.

In the face of climate change, global political and food insecurity, and volatility of global market prices and the resurgence of health crises, only an ambitious, continent -wide policy can safeguard each country's independence. The main focus of the paper is devoted to explaining the incentives and strategies of politicians, economists, agency officials, and environmental advocates. How this web of interactions affects agricultural and food policies, farmers, consumers, welfare and economic growth?

The specific objectives of the study are:

1. To study the effects, benefits and costs of political economy of countries in budget allocation in sectors.

2. To analyse the political economy of countries in preferences of agriculture and other sectors.

3. To analyse the political economy of the impact of international organizations (WTO, WB, IMF) and international trade agreements on agriculture.

4. To analyse the political economy motives behind preferring farmer and consumer welfare.

5. To suggest policies and strategies to adopt the successful political economy of agriculture in the globe.

\section{Data and Methodology}

The study is basically based on political economy of global agriculture and quantitative frame work. The effects of global political economy of agriculture in general and continents \& country-wise in particular from 37 to 170 major countries of 6 continents policies and insights were analyzed. The developed countries of continents viz., European union (15 countries), North America (3 countries viz., USA, Mexico and Canada), Asia (11 countries including china), South America (4 countries), Africa (2 country), and Australia were purposefully selected to analyze the effects of international political economy on global agriculture, trade, farmer and consumers, policy distortions, welfare and economic growth. 
The data and information on global economic systems, key economic indicators, share of sectors, GDP, World Bank lending sector wise, global agricultural domestic support during WTO regime, producer and consumer support and policies collected from FAO, World Bank, IMF, UNDES, WEF, OECD, CGIAR reports and published secondary sources and websites. The secondary data related to Producer Support Estimates and Consumer Support Estimates were collected from OECD Agriculture statistics (database)and growth rates were estimated. Continent-wide policy can safeguard each country's independence. The continent wise policies are critically appraised and compared with one another and best policies are arrived. The study used Delphi survey method to validate the results obtained through secondary data (Dalkey and Helmer, 1963). It also suggests the best future global agricultural policies. The meta analysis, growth rates and agricultural orientation index were estimated.

Growth rate formulae: (Damodar N. Gujarati and Sangeetha, 2007)

The compound growth rate (r) will be calculated by fitting

Exponential function to the variables of interest viz., allocation of funds, Producer Support Estimates and Consumer Support Estimates for the period 1995 to 2018.

Yt - Y0 (1+r)t --------1

Assuming multiplicative error term in the equation1, model may be linearized by logarithmic transformation

$\ln Y \mathrm{t}=\mathrm{A}+\mathrm{Bt}+€$--------2

Where, A $(=\ln \mathrm{Ao})$ and $\mathrm{B}(=\ln (1+\mathrm{r}))$ are the parameters to be estimated by ordinary least square regression, $\mathrm{t}=$ time trend in year, $\mathrm{r}=\exp (\mathrm{B})-1$

Agricultural Orientation Index Formula:

$$
A O I=\frac{\text { Agriculture share of Total Outlays (central govt) }}{\text { Agriculture share of GDP }}
$$

\section{Results and Discussion}

\section{Type of political economic systems:}

The list of countries and their type of economy shown in the table 1. It was found that most of the developed countries are capitalistic and developing countries are socialistic. Only few countries which are communist countries includes China, North Korea, Cuba, Laos and Vietnam. Majority of the countries in the world are mixed economies in operation. These type of economies play an important role in resource allocation and protection of agriculture. 
Table1. List of countries with their type of Economy:

\begin{tabular}{|c|c|c|}
\hline Sl.no & Type of Economy & Countries \\
\hline 1 & Capitalism & $\begin{array}{c}\text { New Zealand, Switzerland, Australia, Canada, United Arab } \\
\text { Emirate, Taiwan, United Kingdom, the Netherlands, the } \\
\text { United States, Denmark, Sweden, South Korea, Thailand, } \\
\text { Japan, Mexico, Germany, Spain, Greece, Belgium, Italy, } \\
\text { France, Austria, South Africa and Norway. }\end{array}$ \\
\hline 2 & Socialism & India. \\
\hline 3 & China, North Korea, Cuba, Laos and Vietnam. \\
\hline 4 & $\begin{array}{c}\text { Nigeria, Indonesia, Iran, Saudi } \\
\text { Arabia, Turkey, Russia, Poland, } \\
\text { Colombia, Argentina, Venezuela, } \\
\text { Brazil. }\end{array}$ & \begin{tabular}{c} 
Refer Appendix I \\
\hline
\end{tabular} \\
\hline
\end{tabular}

\section{Economic indicators of major countries of world}

The key economic indicators of major countries of world are shown in Table 2. The moving average of real world GDP percentage decreasing from 3.3 in 2014 to 2.9 in 2016. The European countries and Japan show an increasing trend, however, the United States, the OECD and Non-OECD countries, Indonesia and Russia display a mixed trend in the real GDP percentage over the years 2014, 2015 and 2016. In synchronous with the world trend, the countries such as Brazil, China, Colombia and South Africa show a decreasing trend. Unemployment rate and World Trade growth rate over the years are decreasing, where as inflation displays a mixed trend. The developed countries real GDP (\%) display either an increasing or a mixed trend and developing countries show a decreasing trend. The decreasing trend of developing countries real GDP (\%) will not enable them to allocate more on agriculture.

Table 2. Key economic indicators of major countries of world

OECD area, unless noted otherwise

$\begin{array}{cccc}\text { Average } & 2014 & 2015 & 2016 \\ 2004-2013 & & \end{array}$

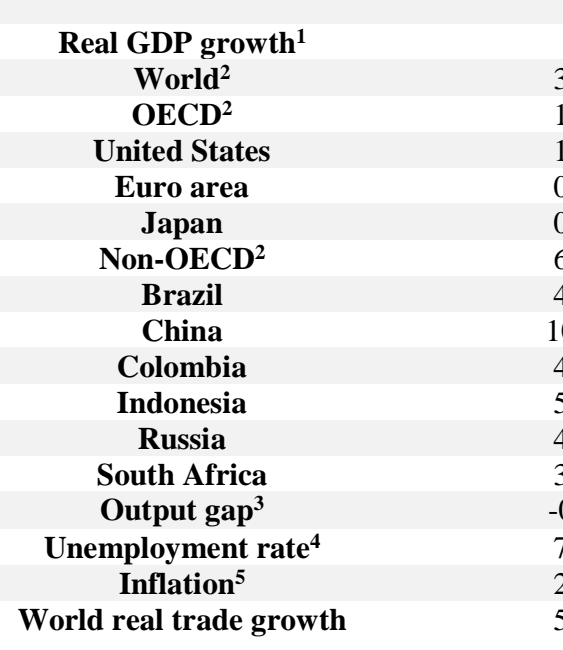

$\begin{array}{cccc}3.9 & 3.3 & 3.1 & 2.9 \\ 1.6 & 1.9 & 2.1 & 1.7 \\ 1.6 & 2.4 & 2.6 & 1.5 \\ 0.8 & 1.2 & 1.5 & 1.7 \\ 0.8 & 0.0 & 0.6 & 0.8 \\ 6.6 & 4.6 & 3.8 & 4.0 \\ 4.0 & 0.1 & -3.9 & -3.4 \\ 10.3 & 7.3 & 6.9 & 6.7 \\ 4.8 & 4.4 & 3.1 & 2.1 \\ 5.7 & 5.0 & 4.8 & 5.0 \\ 4.1 & 0.7 & -3.7 & -0.8 \\ 3.3 & 1.6 & 1.3 & 0.4 \\ -0.5 & -2.1 & -1.5 & -1.4 \\ 7.1 & 7.4 & 6.8 & 6.3 \\ 2.0 & 1.6 & 0.7 & 1.0 \\ 5.3 & 3.9 & 2.6 & 1.9\end{array}$


1. Year-on-year increase; last three columns show the increase over a year earlier.

2. Moving nominal GDP weights, using purchasing power parities.

3. Per cent of potential GDP.

4. Per cent of labour force.

5. Private consumption deflator. Year-on-year increase; last 3 columns show the increase over a year earlier.

Source: OECD (2016), OECD Economic Outlook, Vol. 2016/2, OECD Publishing, Paris. Last updated November 2016.

\section{Comparison of Nominal GDP's of countries in the World}

The Country groups by nominal GDP in the world shown in table 3. All the 7 major advanced economies of G7 have at least $0.5 \%$ of Global GDP. Among the other 32 advanced economies excluding G7, countries such Australia, Austria, Belgium, South Korea, Netherlands, Norway, Spain, Switzerland, Sweden and Taiwan have at least $0.5 \%$ of Global GDP. In case of 30 Emerging and Developing Asian economies, only 4 countries (China, India, Indonesia and Thailand) have at least $0.5 \%$ of Global GDP. In the 32 Latin American and the Caribbean Countries only Argentina, Brazil and Mexico have at least $0.5 \%$ of Global GDP. Among the Middle Eastern countries, North Africa, Afghanistan and Pakistan, the UAE, Saudi Arabia and Iran are major economies with at least $0.5 \%$ of Global GDP. In 12 emerging and developing European countries, Poland and Turkey and in 12 Commonwealth of Independent States and Georgia, Russia have at least $0.5 \%$ of Global GDP. And in 45 Sub-Saharan African Countries only Nigeria has at least $0.5 \%$ of Global GDP. It shows that Africa is the highest backward continent in the world. Those countries which have less than $0.5 \%$ of Global GDP has a disadvantage in budget allocation to agriculture.

Table 3. Country groups by GDP (nominal) in the World in Millions US\$ as on April 2017

\begin{tabular}{|c|c|c|c|c|}
\hline Country Group & $\begin{array}{l}\text { GDP } \\
\text { (Nominal) }\end{array}$ & $\begin{array}{l}\text { Peak } \\
\text { Year }\end{array}$ & $\begin{array}{c}\text { Number } \\
\text { of } \\
\text { Countrie } \\
\text { s }\end{array}$ & $\begin{array}{l}\text { Economies with at least } 0.5 \% \text { of } \\
\text { Global GDP }\end{array}$ \\
\hline $\begin{array}{l}\text { Major advanced } \\
\text { economies (G7) }\end{array}$ & $3,60,06,539$ & 2017 & 7 & $\begin{array}{c}\text { Canada, France, Germany, Italy, } \\
\text { Japan, United Kingdom, United States }\end{array}$ \\
\hline $\begin{array}{l}\text { Emerging and } \\
\text { Developing Asia }\end{array}$ & $1,70,84,823$ & 2017 & 30 & China, India, Indonesia, Thailand \\
\hline $\begin{array}{l}\text { Other Advanced } \\
\text { Economies } \\
\text { (Advanced economies } \\
\text { excluding G7) }\end{array}$ & $1,15,93,086$ & 2014 & 32 & $\begin{array}{l}\text { Australia, Austria, Belgium, South } \\
\text { Korea, Netherlands, Norway, Spain, } \\
\text { Sweden, Switzerland, Taiwan }\end{array}$ \\
\hline $\begin{array}{l}\text { Latin America and } \\
\text { the Caribbean }\end{array}$ & $59,83,936$ & 2013 & 32 & Argentina, Brazil, Mexico \\
\hline $\begin{array}{l}\text { Middle East, North } \\
\text { Africa, Afghanistan, } \\
\text { and Pakistan }\end{array}$ & $34,73,402$ & 2014 & 22 & $\begin{array}{c}\text { Iran, Saudi Arabia, United Arab } \\
\text { Emirates }\end{array}$ \\
\hline
\end{tabular}




\begin{tabular}{|ccccc|}
\hline $\begin{array}{c}\text { Commonwealth of } \\
\text { Independent States } \\
\text { and Georgia }\end{array}$ & $29,43,338$ & 2013 & 12 & Russia \\
\hline $\begin{array}{c}\text { Emerging and } \\
\text { developing Europe }\end{array}$ & $20,31,117$ & 2014 & 12 & Poland, Turkey \\
\hline Sub-Saharan Africa & $16,90,338$ & 2014 & 45 & Nigeria \\
\hline World & $7,85,19,556$ & 2014 & 192 & \\
\hline
\end{tabular}

Source: International Monetary Fund, World Economic Outlook Database, April 2017

\section{The share of sectors in total GDP of countries}

The share of sectors in total GDP of countries and population continent wise is presented in Table 4 . The below 36 countries are the major economies of the world in GDP contribution. In agriculture sector, Nigeria has the maximum (17.8\%) share of GDP among the world countries despite $2.5 \%$ share of world population. It is followed by India, which has $17.2 \%$ share of GDP to the agriculture sector with $17.7 \%$ of the World Populace. The industry share of GDP is maximum in the Saudi Arabia at $69.1 \%$, followed by the UAE (53.9\%), Indonesia (47.2\%), China (46.8\%) and others. The services share of GDP is highest in the USA (79.6\%), followed by France (79.4\%), Greece (78.9\%) and others. The high income economies, as classified by the World Bank such as Japan, Taiwan, Australia, Germany, Netherlands, Switzerland, Spain, Italy, Sweden, Belgium, Poland, United Kingdom, France, Austria, Norway, Denmark, Greece, the USA and Canada have more than 50\% share of service sector in total GDP of the respective countries. And the economies of the US and France have almost service sector share of nearly $80 \%$. Saudi Arabia and the UAE despite being high- income countries show a low service sector share $(28.9 \%, 45.3 \%$ respectively) and high industry sector share $(69.1 \%, 53.9 \%$ respectively), which could be probably attributed to the Oil and petroleum industries. The UK $(0.7 \%)$, Belgium (0.7\%), Germany $(0.8 \%)$ and the UAE $(0.8 \%)$ have the least share of agriculture sector contribution to their GDP's among the major world economies. China with its highest populace in the world seems to balance between its industry (46.8\%) and service $(43.1 \%)$ sectors contribution to their economic GDP.

The agriculture shares in GDP for the developing countries, as per the IMF, such as Nigeria, China, India, Indonesia, Iran, Thailand and Argentina have more than $10 \%$. Whereas, South Africa, Russia, Turkey, Mexico, Colombia, Venezuela and Brazil have less than 10\% share of agriculture in its GDP, despite being developing countries. While, in the case of South Africa $(2.5 \%)$, it is the low availability of arable land contributing to the lowest share of agriculture in its GDP. Rapid urbanization in Colombia during the $20^{\text {th }}$ century has reflected a drop in the agriculture sectors share with increase in industry and services share in GDP. The study found that high dependence on agriculture is observed in most of the developing countries and the high 
income economies are focusing more on ( $>50 \%)$ service sector. Saudi Arabia and the UAE has high industry sector share $(>50 \%)$ which is due to their exploration of oil and petroleum reserves. The more dependence on agriculture will allow the politicians to exploit in the elections.

Table 4. The share of sectors in total GDP of countries and population Continent wise

\begin{tabular}{|c|c|c|c|c|c|c|}
\hline No. & Country/Economy & Agriculture & Industry & Services & Population & $\begin{array}{c}\% \text { Share in } \\
\text { world population }\end{array}$ \\
\hline- & World & 6.1 & 31.1 & 62.9 & $7,46,69,64,280$ & \\
\hline & \multicolumn{6}{|c|}{ AFRICA } \\
\hline 1 & Nigeria & 17.8 & 25.7 & 54.6 & $18,59,89,640$ & 2.5 \\
\hline \multirow[t]{2}{*}{2} & South Africa & 2.5 & 31.6 & 65.9 & $5,60,15,473$ & 0.8 \\
\hline & \multicolumn{6}{|c|}{ ASIA } \\
\hline 1 & China & 10.1 & 46.8 & 43.1 & $1,40,35,00,365$ & 18.8 \\
\hline 2 & Japan & 1.2 & 27.3 & 71.6 & $12,77,48,513$ & 1.7 \\
\hline 3 & India & 17.2 & 26.4 & 56.4 & $1,32,41,71,354$ & 17.7 \\
\hline 4 & Indonesia & 14.7 & 47.2 & 38.1 & $26,11,15,456$ & 3.5 \\
\hline 5 & United Arab Emirates & 0.8 & 53.9 & 45.3 & $92,69,612$ & 0.1 \\
\hline 6 & Iran & 10.4 & 37.7 & 51.8 & $8,02,77,428$ & 1.1 \\
\hline 7 & Saudi Arabia & 2 & 69.1 & 28.9 & $3,22,75,687$ & 0.4 \\
\hline 8 & South Korea & 2.6 & 39.2 & 58.2 & $5,07,91,919$ & 0.7 \\
\hline 9 & Thailand & 13.3 & 34 & 52.7 & $6,88,63,514$ & 0.9 \\
\hline 10 & Taiwan & 1.3 & 32 & 66.9 & $2,35,56,706$ & 0.3 \\
\hline \multirow[t]{2}{*}{11} & Turkey & 9.3 & 28.1 & 62.6 & $7,95,12,426$ & 1.1 \\
\hline & \multicolumn{6}{|c|}{ AUSTRALASIAN } \\
\hline \multirow[t]{2}{*}{1} & Australia & 3.6 & 28.2 & 68.2 & $2,41,25,848$ & 0.3 \\
\hline & \multicolumn{6}{|c|}{ EUROPE } \\
\hline 1 & Germany & 0.8 & 28.6 & 70.6 & $8,19,14,672$ & 1.1 \\
\hline 2 & Netherlands & 2.7 & 24.2 & 73.1 & $1,69,87,330$ & 0.2 \\
\hline 3 & Russia & 4.5 & 36.9 & 58.6 & $14,39,64,513$ & 1.9 \\
\hline 4 & Switzerland & 1.3 & 27.5 & 71.3 & $84,01,739$ & 0.1 \\
\hline 5 & Spain & 3.2 & 25.8 & 71 & $4,63,47,576$ & 0.6 \\
\hline 6 & Italy & 2 & 24.7 & 73.4 & $5,94,29,938$ & 0.8 \\
\hline 7 & Sweden & 1.8 & 27.3 & 70.9 & $98,37,533$ & 0.1 \\
\hline 8 & Belgium & 0.7 & 21.7 & 77.6 & $1,13,58,379$ & 0.2 \\
\hline 9 & Poland & 3.4 & 33.6 & 63 & $3,82,24,410$ & 0.5 \\
\hline 10 & United Kingdom & 0.7 & 21.4 & 77.8 & $6,57,88,574$ & 0.9 \\
\hline 11 & France & 1.8 & 18.8 & 79.4 & $6,47,20,690$ & 0.9 \\
\hline 12 & Austria & 1.5 & 29.4 & 69.1 & $87,12,137$ & 0.1 \\
\hline 13 & Norway & 2.6 & 39.7 & 57.7 & $52,54,694$ & 0.1 \\
\hline 14 & Denmark & 4.5 & 19.1 & 76.4 & $57,11,870$ & 0.1 \\
\hline \multirow[t]{2}{*}{15} & Greece & 3.3 & 17.9 & 78.9 & $1,11,83,716$ & 0.1 \\
\hline & \multicolumn{6}{|c|}{ NORTH AMERICA } \\
\hline 1 & United States & 1.2 & 19.2 & 79.6 & $32,21,79,605$ & 4.3 \\
\hline 2 & Canada & 1.9 & 27.1 & 71 & $3,62,89,822$ & 0.5 \\
\hline \multirow[t]{2}{*}{3} & Mexico & 3.8 & 34.2 & 62 & $12,75,40,423$ & 1.7 \\
\hline & \multicolumn{6}{|c|}{ SOUTH AMERICA } \\
\hline 1 & Colombia & 7 & 37.6 & 55.5 & $4,86,53,419$ & 0.7 \\
\hline 2 & Argentina & 11.4 & 30.2 & 58.4 & $4,38,47,430$ & 0.6 \\
\hline 3 & Venezuela & 3.8 & 35.8 & 60.4 & $3,15,68,179$ & 0.4 \\
\hline 4 & Brazil & 5.5 & 27.5 & 67 & $20,76,52,865$ & 2.8 \\
\hline
\end{tabular}

Source: Population - United Nations Department of Economic and Social Affairs, Population Division, Population Estimates and Projections Section. June 2017 


\section{The nominal GDP and agriculture orientation index of the countries:}

Any country's budget allocation determines the political economy of sectors. The nominal GDP of the major 36 countries, the total outlays of the central governments and the agriculture orientation index is given in Table 5. As per the FAO, The Agriculture Orientation Index (AOI) for government expenditures is defined as the Agriculture Share of Government Expenditures, divided by the Agriculture Share of GDP, where agriculture refers to the agriculture, forestry, fishing and hunting sector. Agriculture Orientation Index indicates political cost and political benefits. An Agriculture Orientation Index (AOI) greater than 1 reflects a higher orientation towards the agriculture sector, which receives a higher share of government spending relative to its contribution to economic value-added. An AOI less than 1 reflects a lower orientation to agriculture, while an AOI equal to 1 reflects neutrality in a government's orientation to the agriculture sector.

The political economy of AOI indicates that the countries which have more than 1 will spend more budget in budget allocation towards agriculture. The study found that, clearly agriculture globally is not on the priority list for the local central governments in allocating their budgets towards agriculture, except for South Korea and Switzerland, whose agriculture orientation index is greater than 1(1.96 and 5.08 respectively).

Table 5. Nominal GDP sector composition 2015 (in percentage and in millions of dollars)

\begin{tabular}{|c|c|c|c|c|c|}
\hline № & $\begin{array}{c}\text { Country/Ec } \\
\text { onomy }\end{array}$ & $\begin{array}{l}\text { Nominal GDP (in } \\
\text { Million \$) }\end{array}$ & $\begin{array}{l}\text { Agri. Share in } \\
\text { GDP }(\%)\end{array}$ & $\begin{array}{l}\text { Total } \\
\text { outlays } \\
2015 \\
\text { (Central } \\
\text { Governme } \\
\text { nt) (in } \\
\text { Million \$) }\end{array}$ & $\begin{array}{c}\text { Agriculture } \\
\text { orientation index }\end{array}$ \\
\hline \multirow[t]{2}{*}{-} & World & $7,52,12,696$ & $5.90 \%$ & & \\
\hline & AFRICA & & & & \\
\hline 1 & Nigeria & $4,15,080$ & $17.80 \%$ & & \\
\hline \multirow[t]{2}{*}{2} & South Africa & $3,41,216$ & $2.50 \%$ & 60254.34 & 0.68845 \\
\hline & ASIA & & & & \\
\hline 1 & China & $1,12,18,281$ & $6.90 \%$ & 410151.69 & 0.31944 \\
\hline 2 & Japan & $47,30,300$ & $1.20 \%$ & 760577.81 & \\
\hline 3 & India & $22,50,990$ & $17.40 \%$ & & 0.000769 \\
\hline 4 & Indonesia & $9,40,953$ & $14.30 \%$ & 134821.07 & \\
\hline 5 & $\begin{array}{l}\text { United Arab } \\
\text { Emirates }\end{array}$ & $4,16,444$ & $0.70 \%$ & 17506.14 & 0.05023 \\
\hline 6 & Iran & $4,12,340$ & $11.20 \%$ & & \\
\hline 7 & $\begin{array}{r}\text { Saudi } \\
\text { Arabia }\end{array}$ & $6,57,785$ & $2 \%$ & & \\
\hline 8 & South Korea & $14,04,380$ & $2.70 \%$ & 297256.6 & 1.96439 \\
\hline 9 & Thailand & $3,90,592$ & $13.30 \%$ & 75187.49 & 0.83418 \\
\hline 10 & Taiwan & $5,19,149$ & $1.30 \%$ & & \\
\hline \multirow[t]{2}{*}{11} & Turkey & $7,55,716$ & $8.90 \%$ & 277290.12 & 0.39941 \\
\hline & AUSTRALAS & & & & \\
\hline \multirow[t]{2}{*}{1} & Australia & $12,56,640$ & $4 \%$ & 326570.64 & 0.23684 \\
\hline & EUROPE & & & & \\
\hline 1 & Germany & $34,94,900$ & $0.80 \%$ & 425433.58 & \\
\hline 2 & Netherlands & $7,69,930$ & $2.80 \%$ & 310458.85 & 0.22548 \\
\hline 3 & Russia & $12,67,750$ & $3.90 \%$ & 451002.73 & 0.17643 \\
\hline
\end{tabular}




\begin{tabular}{|c|c|c|c|c|c|}
\hline 4 & Switzerland & $6,62,483$ & $1.30 \%$ & 117416.31 & 5.08178 \\
\hline 5 & Spain & $12,52,160$ & $3.30 \%$ & 418114.85 & 0.08045 \\
\hline 6 & Italy & $18,52,500$ & $2 \%$ & 537402.74 & 0.16724 \\
\hline 7 & Sweden & $5,17,440$ & $1.80 \%$ & 147381.2 & 0.38457 \\
\hline 8 & Belgium & $4,70,179$ & $0.70 \%$ & 125407.29 & 0.00004 \\
\hline 9 & Poland & $4,67,350$ & $3.40 \%$ & 188586.55 & 0.38103 \\
\hline 10 & $\begin{array}{c}\text { United } \\
\text { Kingdom }\end{array}$ & $26,49,890$ & $0.70 \%$ & 1124398.57 & 0.45754 \\
\hline 11 & France & $24,88,280$ & $1.90 \%$ & 1115984.03 & 0.2045 \\
\hline 12 & Austria & $3,87,299$ & $1.50 \%$ & 177453.82 & \\
\hline 13 & Norway & $3,76,268$ & $2.70 \%$ & 150895.81 & 0.93762 \\
\hline 14 & Denmark & $3,47,196$ & $4.50 \%$ & 124401.99 & 0.39976 \\
\hline 15 & Greece & $2,46,397$ & $3.30 \%$ & 105728.45 & 0.11949 \\
\hline \multicolumn{6}{|c|}{ NORTH AMERICA } \\
\hline 1 & $\begin{array}{l}\text { United } \\
\text { States }\end{array}$ & $1,79,46,996$ & $1.12 \%$ & 2405200 & \\
\hline 2 & Canada & $15,32,340$ & $1.80 \%$ & & \\
\hline 3 & Mexico & $10,63,610$ & $3.70 \%$ & & \\
\hline \multicolumn{6}{|c|}{ SOUTH AMERICA } \\
\hline 1 & Colombia & $4,00,117$ & $8.90 \%$ & 66126.09 & \\
\hline 2 & Argentina & $5,41,784$ & $10 \%$ & 165216.11 & 0.09439 \\
\hline 3 & Venezuela & $2,09,226$ & $4.70 \%$ & & \\
\hline 4 & Brazil & $17,69,600$ & $5.40 \%$ & 496545.66 & 0.14801 \\
\hline
\end{tabular}

Sources: The World Bank _ Agri. Share \% GDP

Share of different sectors - "The World Fact book - Central Intelligence Agency". Central Intelligence Agency. September 2017.

Total Outlays, Agriculture Orientation Index _ FAO STAT

\section{Political Economy of International Financial Institutions}

The World Bank Group is one of the world's largest sources of funding and knowledge for developing countries, consisting of five institutions with a common commitment to reducing poverty, increasing shared prosperity, and promoting sustainable development. The World Bank Group consists, International Bank for Reconstruction and Development (IBRD), International Development Association (IDA), International Finance Corporation (IFC), Multilateral Investment Guarantee Agency (MIGA) and International Centre for the Settlement of Investment Disputes (ICSID). The institutions IBRD and IDA play a major role in the agriculture sector in middle-income and creditworthy low-income countries of the world.

World Bank lending by sector wise for the fiscal years $2011-2015$ is given in Table 6. World Bank lending has been the highest to Public administration, law and justice sector in all the years and the least to information and communications. Agriculture, Fishing and Forestry has been given low to medium preference among various sectors by the major lending institutions of the world. Political economy of international financial institutions displays high priority to Public administration, law and justice sectors and a poor treatment towards the agriculture sector 
Table 6. World Bank lending sector wise: fiscal 2011-15 (Millions of dollars)

\begin{tabular}{c|ccccc} 
SECTOR & $F Y 11$ & $F Y 12$ & $F Y 13$ & $F Y 14$ & $F Y 15$ \\
\hline Agriculture, Fishing and Forestry & 2,128 & 3,134 & 2,112 & 3,059 & 3,027 \\
Education & 1,733 & 2,959 & 2,731 & 3,457 & 3,534 \\
Energy and Mining & 5,807 & 5,000 & 3,280 & 6,689 & 4,510 \\
Finance & 897 & 1,764 & 2,055 & 1,984 & 4,054 \\
Health and Other Social Services & 6,707 & 4,190 & 4,363 & 3,353 & 6,647 \\
Industry and Trade & 2,167 & 1,352 & 1,432 & 1,807 & 2,311 \\
Information and Communications & 640 & 158 & 228 & 381 & 322 \\
Public Administration, Law and Justice & 9,673 & 8,728 & 7,991 & 8,837 & 8,180 \\
Transportation & 8,683 & 4,445 & 5,135 & 6,946 & 5,151 \\
Water, Sanitation, and Flood Protection & 4,617 & 3,605 & 2,220 & 4,332 & 4,760 \\
Sector Total & 43,006 & 35,335 & 31,547 & 40,843 & 42,495 \\
Of which IBRD & 26,737 & 20,582 & 15,249 & 18,604 & 23,528 \\
Of which IDA & 16,269 & 14,753 & 16,298 & 22,239 & 18,966
\end{tabular}

Note: Numbers may not add to totals because of rounding Source: World Bank Annual Report 2015

The active portfolio net commitments for the major regions of the world given in Table 7 for the year 2015. IDA being a developmental agency working for the poorest countries offers maximum support to African regions, followed by South Asia and others. IBRD focuses more on the low and middle income countries with its major support in Latin American and the Caribbean, Europe and Central Asia, East Asia and Pacific. The study observed that Middle East and North African Countries are funded extremely low in comparison to other regions of the world by IDA and IBRD. This could be due to the political instability and terrorism, which hinders the growth of the regions.

Table 7. Active portfolio net commitments (Billions of dollars, as of June 30, 2015)

\begin{tabular}{c|ccc} 
REGION & IBRD & IDA & TOTAL \\
\hline Africa & 5.1 & 46.9 & 52.0 \\
East Asia and Pacific & 22.6 & 9.0 & 31.6 \\
Europe and Central Asia & 23.8 & 2.4 & 26.2 \\
Latin America and the Caribbean & 25.0 & 2.0 & 27.0 \\
Middle East and North Africa & 10.6 & 1.1 & 11.7 \\
South Asia & 15.4 & 28.0 & 43.5 \\
Total & 102.5 & 89.5 & 191.9
\end{tabular}

Source: World Bank Annual Report 2015

The allocation of funds to various countries by the World Banks for the years 2014-2018 is given in Table 8. The growth rates from 2014 to 2018 have been calculated accordingly. The growth rates for the countries China, Indonesia and Colombia are positive at $14.44 \%, 16.08 \%$ and $24.54 \%$ respectively. The negative growth rates are observed for Nigeria $(-9.26 \%)$, India $(-23.22 \%)$, Mexico (-4.02\%) and Brazil (-66.89\%). There is a sudden 
surge of funds in 2015 to Argentina and the growth rate since 2014 is $829.33 \%$. The first democratic elections in Argentina at the end of 2015 led to a significant change in the economic policies of the country coupled with the new administrations speedy implementations of the core reforms. The study observed the sudden increase of funds to Argentina and decreased funding for the countries Nigeria, India, Mexico and Brazil.

Table 8. Allocation of Funds to various countries by the World Banks for the year 2014-18

\begin{tabular}{|c|c|c|c|c|c|c|c|}
\hline № & Country/Economy & 2014 & 2015 & 2016 & 2017 & 2018 & $\begin{array}{c}\text { Growth } \\
\text { rate } \\
\text { from } \\
2014- \\
2018 \\
(\%)\end{array}$ \\
\hline & \multicolumn{7}{|c|}{ AFRICA } \\
\hline 1 & Nigeria & 2022.6 & 1475 & 1075 & 1511 & & -9.26 \\
\hline \multirow[t]{2}{*}{2} & South Africa & & & & 93 & & \\
\hline & \multicolumn{7}{|c|}{ ASIA } \\
\hline 1 & China & 1648.2 & 1855.6 & 1994.5 & 2470.1 & 402.7 & 14.44 \\
\hline 2 & Japan & & & - & & & \\
\hline 3 & India & 5109.4 & 3820.1 & 3844.5 & 2312.5 & 844.1 & -23.22 \\
\hline 4 & Indonesia & 1085.5 & 1000 & 1700 & 1697.8 & 300 & 16.08 \\
\hline \multirow[t]{4}{*}{5} & $\begin{array}{c}\text { United Arab Emirates, Iran, Saudi } \\
\text { Arabia, South Korea, Thailand, Taiwan, } \\
\text { Turkey }\end{array}$ & \multicolumn{5}{|c|}{ - } & \\
\hline & AUSTRALASIAN (All countries) & \multicolumn{5}{|c|}{-} & \\
\hline & EUROPE (All countries) & \multicolumn{5}{|c|}{-} & \\
\hline & \multicolumn{7}{|c|}{ NORTH AMERICA } \\
\hline 1 & United States, Canada & \multicolumn{5}{|c|}{-} & \\
\hline 2 & Mexico & 395.9 & 866.9 & 500 & 350 & & -4.02 \\
\hline & \multicolumn{6}{|c|}{ SOUTH AMERICA } & \\
\hline 1 & Colombia & 873.3 & 1410.4 & 1400 & 1686.7 & 512 & 24.54 \\
\hline 2 & Argentina & 1.9 & 1343.1 & 1000 & 1525 & & 829.33 \\
\hline 3 & Venezuela & \multicolumn{5}{|c|}{-} & \\
\hline 4 & Brazil & 2019.7 & 568.2 & 758 & 73.3 & 50 & -66.89 \\
\hline
\end{tabular}

Source: World Bank Open Data

\section{Political Economy of International Trade Institutions}

Of late, globally, during WTO regime international political economy play greater role in agriculture protection and policy distortions. The international trade in the hands of politicians in terms of duties, QR's and export import subsidies, policy economists play minimum role in these areas. Trade lobby often government choice of policy. Political organization schemes influence lobby. Larger firm better lobbying power.

\section{Political Institutions: WTO}

The numerical targets for agriculture during the Uruguay Round are given in Table 9. The average cut for all agricultural products for the developed countries up to 6 years is at $-36 \%$ and for developing countries it is given at $-24 \%$ up to 10 years. Whereas, the Total Aggregate Measure Support cut for agriculture is kept at $-20 \%$ for the developed countries up to 6 years and for developing countries it is given at $-13 \%$ up to 10 years. These targets 
are not followed in many WTO member countries which have comparative advantage.

Table 9: Numerical targets for agriculture During Uruguay Round

\begin{tabular}{|c|c|c|}
\hline Target Variables & $\begin{array}{l}\text { Developed Countries } \\
\text { 6 years: 1995 to 2000 }\end{array}$ & $\begin{array}{c}\text { Developing Countries } \\
\text { 10 years:1995 to 2004 }\end{array}$ \\
\hline \multicolumn{3}{|c|}{ Tariffs } \\
\hline Average cut for all agricultural products & $-36 \%$ & $-24 \%$ \\
\hline Minimum cut per products & $-15 \%$ & $-10 \%$ \\
\hline \multicolumn{2}{|c|}{ Domestic Support } \\
\hline $\begin{array}{c}\text { Total AMS cut for sector } \\
\text { (base period:1986-88) }\end{array}$ & $-20 \%$ & $-13 \%$ \\
\hline \multicolumn{2}{|c|}{ Exports } \\
\hline & $-36 \%$ & $-24 \%$ \\
\hline Sulue of Subsidies & $-21 \%$ & $-14 \%$ \\
\hline
\end{tabular}

Source: Agriculture: fairer markets for farmers, WTO Website, Accessed on $5^{\text {th }}$ September, 2017

\section{Global Agricultural Domestic Support}

Agricultural support is defined as the annual monetary value of gross transfers to agriculture from consumers and taxpayers arising from government policies that support agriculture, regardless of their objectives and economic impacts (OECD, 2017). The compound annual growth rates of global agricultural supports (2000-2016) were presents in Table 10. During 2000-2016, the highest and positive growth rates in agricultural support were observed in Russia (22.68 \%) followed by India (20.19\%), China (19.93 \%), New Zealand (12.34 \%), Philippines (6.41 \%), Costa Rica (6.36\%) and Brazil (6.01). During the same period, the negative growth rates in agricultural support were observed in Mexico (-3.44 \%), Chile (-2.59 \%), USA (-2.47 \%), Japan $(-1.52 \%)$ and OECD (-0.37 \%) members. The study found that during the period 2000 to 2016, Russia, India, China and New Zealand are given more domestic support and Mexico, Chile, USA, Japan and OECD countries were given decreasing support to agricultural sector than compared to other WTO member countries.

Table 10: CAGR of Agricultural Domestic Support of Major Countries (2000-01 to 2015-

16)

\begin{tabular}{|c|c|c|c|}
\hline Country & \begin{tabular}{|}
$2001-01$ (Million US \\
\$)
\end{tabular} & \begin{tabular}{|c|}
$2015-16$ (Million US \\
$\$$ )
\end{tabular} & Growth Rates (\%) \\
\hline \multicolumn{4}{|c|}{ AFRICA } \\
\hline Nigeria & - & - & - \\
\hline South Africa & - & - & - \\
\hline \multicolumn{4}{|c|}{ ASIA } \\
\hline Japan & 54087.760289 & 41666.362575 & -1.52 \\
\hline Philippines & 2178.844683 & 6263.9232717 & 6.41 \\
\hline India & 1711.1651614 & 35969.07528 & 20.97 \\
\hline Turkey & 9035.9132087 & 17182.470971 & 3.85 \\
\hline China & 9653.5109856 & 212182.44246 & 19.93 \\
\hline
\end{tabular}




\begin{tabular}{|c|c|c|c|}
\hline New Zealand & 19.710724668 & 142.44130871 & 12.34 \\
\hline Russia & 369.39297734 & 11927.501871 & 22.68 \\
\hline Korea & 19259.316117 & 20039.270887 & 0.23 \\
\hline Israel & 786.231704 & 1361.0379525 & 3.28 \\
\hline \multicolumn{4}{|c|}{ AUSTRALASIAN } \\
\hline Australia & 780.04101778 & 890.21761192 & 0.78 \\
\hline \multicolumn{4}{|c|}{ EUROPE } \\
\hline Norway & 2153.0054632 & 3128.3623498 & 2.22 \\
\hline Switzerland & 5481.17354 & 7288.1231953 & 1.69 \\
\hline Ice land & 153.46424787 & 222.30802092 & 2.20 \\
\hline European Union (28 Countries) & 87824.861824 & 99735.092058 & 0.75 \\
\hline \multicolumn{5}{|c|}{ NORTH AMERICA } \\
\hline Mexico & 7604.6223222 & 4194.500000 & -3.44 \\
\hline Canada & 4335.3820311 & 4777.1896215 & 0.57 \\
\hline United States of America & 50880.500624 & 33277.271943 & -2.47 \\
\hline Costa Rica & 187.62505661 & 535.52379232 & 6.36 \\
\hline \multicolumn{4}{|c|}{ SOUTH AMERICA } \\
\hline Chile & 562.3029226 & 359.9737062 & -2.59 \\
\hline Brazil & 2727.5682198 & 7362.2856907 & 6.01 \\
\hline Colombia & 2342.3570188 & 3297.0799012 & 2.03 \\
\hline OECD Member Countries & 242964.28604 & 228052.49612 & -0.37 \\
\hline
\end{tabular}

Source: OECD Data, Accessed on 29 September, 2017

\section{Government Protection of Farmer and Consumer}

The Producer and Consumer support estimates, their percentages, Nominal Protection Coefficients, Nominal Assistance Coefficients of the various countries, continent wise are given in the Table 11. The growth rates have been calculated from 1995-97 to 2014-16. South Africa being a capitalistic democracy protects neither the producer nor the consumer. However, the producer support estimates growth rate is higher than the consumer support estimates growth rate in South Africa. In case of capitalistic Australasian countries, the welfare state New Zealand under monarchy supports both the producers and the consumers with PSE growth rates of $4.34 \%$ and CSE growth rates of $6.53 \%$. Australia being a constitutional monarchy supports the producers over the consumers with growth rates of $1.87 \%$ for PSE and $-100 \%$ for CSE. Among the Asian countries Korea, China, Indonesia and Vietnam support the consumers over the producers. Whereas, Kazakhstan, Turkey, Israel and Japan supports the producers over the consumers. In the European nations, Iceland, Norway and Russia support the consumers over the producers in contrast to the Switzerland's and Ukraine's way of support. In North and South America only the large economies such as Canada, the USA and Brazil support the consumers over the producers. Basically the political economy of protecting producer and consumer depends upon their share of votes in elections. Capitalistic countries protect more producer compared to consumer, contrastingly, socialist or mixed economies 
protect more consumer because of political benefits in elections. (Consumers $100 \%$ votes).

\section{Support to producers and consumers}

In general, when the governments support the producer, there is rise in inflation and the consumer is affected with price rise which in turn reflects as less economic growth at national level. On an international level, international prices of commodities fall down, trade is effected and world growth slows down. Reasons for supporting producer could be farmers lobby and votes in elections. Protection of producers beyond the specified limits is also against the WTO-AOA. For the period of 2014-2016, the countries such as South Africa, Australia, New Zealand, Japan, Korea, Israel, Turkey, China, Indonesia, Kazakhstan, Philippines, Vietnam, European Union, Iceland, Norway, Switzerland, Russia, Canada, the USA, Mexico, Costa Rica, Chile, Brazil, Colombia, and OECD show Producer Support Estimates to be higher than the Consumer Support Estimates.

When the governments support the consumer, the producer is adversely affected. However, the economic growth improves accompanied by more trade and easy market access resulting in more taxes. Also, the international trade improves and WTO AOA would be satisfied. This scenario could be observed only in the case of Ukraine for the years 1995-97 and 201416. Predominantly, in developed nations, producers are more supported in contrast to the developing countries, where consumers are more protected. The tax burden on the consumer increases with the support to the producer. The regulating agencies such as the hierarchical bureaucracy avoid budget deficits. Ministry of Agriculture protects off-budget programs like tariffs and quotas which affects access of export markets. Intervention of governments in the agriculture sector, is a necessity as it is not a profitable business. Also, governments in various countries have been protecting agriculture since ages. In fact, developed countries protect more agriculture. Inflation tackling is a problem for poverty - ridden countries, which puts an obligation to protect the consumer. 
Table 11. Producer and Consumer support estimates with growth rates

\begin{tabular}{|c|c|c|c|c|c|c|c|c|c|}
\hline \multicolumn{4}{|c|}{ Producer Support Estimate by country } & \multicolumn{6}{|c|}{ Consumer Support Estimate by country } \\
\hline $\begin{array}{c}\text { Continent/Cou } \\
\text { ntry }\end{array}$ & $\begin{array}{c}198 \\
6-88\end{array}$ & $\begin{array}{c}1995 \\
-97\end{array}$ & $\begin{array}{c}2014 \\
-16\end{array}$ & $\begin{array}{c}\text { Grow } \\
\text { th } \\
\text { Rate } \\
(\%)\end{array}$ & $\begin{array}{c}\text { Continent/Cou } \\
\text { ntry }\end{array}$ & $\begin{array}{c}1986 \\
-88\end{array}$ & $\begin{array}{c}1995 \\
-97\end{array}$ & $\begin{array}{c}2014 \\
-16\end{array}$ & $\begin{array}{c}\text { Grow } \\
\text { th } \\
\text { Rate } \\
(\%)\end{array}$ \\
\hline \multicolumn{4}{|c|}{ AFRICA } & \multicolumn{6}{|c|}{ AFRICA } \\
\hline \multicolumn{4}{|c|}{ South Africa $^{1}$} & \multicolumn{6}{|c|}{ South Africa $^{1}$} \\
\hline $\begin{array}{l}\text { PSE (million } \\
\text { USD) }\end{array}$ &.. & 970 & 585 & -2.50 & $\begin{array}{l}\text { CSE (million } \\
\text { USD) }\end{array}$ &.. & -965 & -402 & -4.28 \\
\hline $\begin{array}{l}\text { Percentage } \\
\text { PSE }(\%)\end{array}$ &. & 10.6 & 3.2 & & $\begin{array}{l}\text { Percentage } \\
\text { CSE }(\%)\end{array}$ & .. & -11.3 & -2.3 & \\
\hline $\begin{array}{c}\text { Producer } \\
\text { NAC (coeff.) }\end{array}$ & .. & 1.12 & 1.03 & & $\begin{array}{c}\text { Consumer NPC } \\
\text { (coeff.) }\end{array}$ & .. & 1.13 & 1.02 & \\
\hline \multicolumn{4}{|c|}{ AUSTRALASIAN } & \multicolumn{6}{|c|}{ AUSTRALASIAN } \\
\hline \multicolumn{4}{|c|}{ Australia } & \multicolumn{6}{|c|}{ Australia } \\
\hline $\begin{array}{l}\text { PSE (million } \\
\text { USD) }\end{array}$ & $\begin{array}{c}150 \\
6\end{array}$ & 1282 & 879 & -1.87 & $\begin{array}{l}\text { CSE (million } \\
\text { USD) }\end{array}$ & -600 & -267 & 0 & $\begin{array}{c}- \\
100.0 \\
0\end{array}$ \\
\hline $\begin{array}{l}\text { Percentage } \\
\text { PSE }(\%)\end{array}$ & 10.3 & 5.8 & 1.9 & & $\begin{array}{l}\text { Percentage } \\
\text { CSE }(\%)\end{array}$ & -11.7 & -3.4 & 0.0 & \\
\hline $\begin{array}{c}\text { Producer NPC } \\
\text { (coeff.) }\end{array}$ & 1.08 & 1.03 & 1.00 & & $\begin{array}{c}\text { Consumer NPC } \\
\text { (coeff.) }\end{array}$ & 1.13 & 1.04 & 1.00 & \\
\hline \multicolumn{4}{|c|}{ New Zealand } & \multicolumn{6}{|c|}{ New Zealand } \\
\hline $\begin{array}{l}\text { PSE (million } \\
\text { USD) }\end{array}$ & 429 & 53 & 124 & 4.34 & $\begin{array}{l}\text { CSE (million } \\
\text { USD) }\end{array}$ & -53 & -24 & -85 & 6.53 \\
\hline $\begin{array}{l}\text { Percentage } \\
\text { PSE }(\%)\end{array}$ & 10.3 & 0.8 & 0.8 & & $\begin{array}{l}\text { Percentage } \\
\text { CSE }(\%)\end{array}$ & -5.6 & -1.6 & -3.1 & \\
\hline $\begin{array}{c}\text { Producer NPC } \\
\text { (coeff.) }\end{array}$ & 1.02 & 1.00 & 1.01 & & $\begin{array}{c}\text { Consumer NPC } \\
\text { (coeff.) }\end{array}$ & 1.06 & 1.02 & 1.03 & \\
\hline \multicolumn{4}{|c|}{ ASIA } & \multicolumn{6}{|c|}{ ASIA } \\
\hline \multicolumn{4}{|c|}{ Japan } & \multicolumn{6}{|c|}{ Japan } \\
\hline $\begin{array}{l}\text { PSE (million } \\
\text { USD) }\end{array}$ & $\begin{array}{c}497 \\
57\end{array}$ & $\begin{array}{c}5889 \\
1\end{array}$ & $\begin{array}{c}3981 \\
7\end{array}$ & -1.94 & $\begin{array}{l}\text { CSE (million } \\
\text { USD) }\end{array}$ & $\begin{array}{c}- \\
6128 \\
4\end{array}$ & $\begin{array}{c}- \\
7619 \\
9 \\
\end{array}$ & $\begin{array}{c}- \\
4559 \\
5\end{array}$ & -2.54 \\
\hline $\begin{array}{l}\text { Percentage } \\
\text { PSE }(\%)\end{array}$ & 64.0 & 58.2 & 47.0 & & $\begin{array}{l}\text { Percentage } \\
\text { CSE }(\%)\end{array}$ & -62.3 & -53.7 & -39.9 & \\
\hline $\begin{array}{c}\text { Producer NPC } \\
\text { (coeff.) }\end{array}$ & 2.65 & 2.30 & 1.75 & & $\begin{array}{c}\text { Consumer NPC } \\
\text { (coeff.) }\end{array}$ & 2.65 & 2.16 & 1.66 & \\
\hline \multicolumn{4}{|c|}{ Korea } & \multicolumn{6}{|c|}{ Korea } \\
\hline $\begin{array}{l}\text { PSE (million } \\
\text { USD) }\end{array}$ & $\begin{array}{c}120 \\
40\end{array}$ & $\begin{array}{c}2308 \\
0\end{array}$ & $\begin{array}{c}2068 \\
8\end{array}$ & -0.55 & $\begin{array}{l}\text { CSE (million } \\
\text { USD) }\end{array}$ & $\begin{array}{c}- \\
1178 \\
6 \\
\end{array}$ & $\begin{array}{c}- \\
2377 \\
7\end{array}$ & $\begin{array}{c}- \\
2185 \\
7\end{array}$ & -0.42 \\
\hline $\begin{array}{l}\text { Percentage } \\
\text { PSE }(\%)\end{array}$ & 70.0 & 66.9 & 49.3 & & $\begin{array}{l}\text { Percentage } \\
\text { CSE }(\%)\end{array}$ & -65.9 & -64.9 & -45.2 & \\
\hline $\begin{array}{c}\text { Producer NPC } \\
\text { (coeff.) }\end{array}$ & 3.31 & 2.91 & 1.89 & & $\begin{array}{c}\text { Consumer NPC } \\
\text { (coeff.) }\end{array}$ & 2.94 & 2.87 & 1.83 & \\
\hline \multicolumn{4}{|c|}{ Israel $^{1,3}$} & \multicolumn{6}{|c|}{ Israel $^{1,3}$} \\
\hline $\begin{array}{l}\text { PSE (million } \\
\text { USD) }\end{array}$ & .. & 810 & 1269 & 2.27 & $\begin{array}{l}\text { CSE (million } \\
\text { USD) }\end{array}$ &.. & -722 & -955 & 1.41 \\
\hline $\begin{array}{l}\text { Percentage } \\
\text { PSE }(\%)\end{array}$ & .. & 20.7 & 15.7 & & $\begin{array}{l}\text { Percentage } \\
\text { CSE }(\%)\end{array}$ & .. & -19.6 & -11.5 & \\
\hline $\begin{array}{l}\text { Producer NPC } \\
\text { (coeff.) }\end{array}$ & .. & 1.19 & 1.13 & & $\begin{array}{c}\text { Consumer NPC } \\
\text { (coeff.) }\end{array}$ & .. & 1.25 & 1.13 & \\
\hline \multicolumn{4}{|c|}{ Turkey } & \multicolumn{6}{|c|}{ Turkey } \\
\hline $\begin{array}{l}\text { PSE (million } \\
\text { USD) }\end{array}$ & $\begin{array}{c}432 \\
6\end{array}$ & 8079 & $\begin{array}{c}1715 \\
9\end{array}$ & 3.84 & $\begin{array}{l}\text { CSE (million } \\
\text { USD) }\end{array}$ & $\begin{array}{l}- \\
3125\end{array}$ & $\begin{array}{c}- \\
5552\end{array}$ & $\begin{array}{c}- \\
1068 \\
5\end{array}$ & 3.33 \\
\hline $\begin{array}{l}\text { Percentage } \\
\text { PSE }(\%)\end{array}$ & 22.8 & 29.0 & 26.5 & & $\begin{array}{l}\text { Percentage } \\
\text { CSE }(\%)\end{array}$ & -22.8 & -25.4 & -22.3 & \\
\hline
\end{tabular}




\begin{tabular}{|c|c|c|c|c|c|c|c|c|c|}
\hline $\begin{array}{c}\text { Producer NPC } \\
\text { (coeff.) }\end{array}$ & 1.23 & 1.28 & 1.31 & & $\begin{array}{c}\text { Consumer NPC } \\
\text { (coeff.) }\end{array}$ & 1.30 & 1.35 & 1.29 & \\
\hline \multicolumn{4}{|c|}{ China $^{1}$} & \multicolumn{6}{|c|}{ China $^{1}$} \\
\hline $\begin{array}{l}\text { PSE (million } \\
\text { USD) }\end{array}$ &.. & 6667 & $\begin{array}{l}215 \\
271\end{array}$ & 18.97 & $\begin{array}{l}\text { CSE (million } \\
\text { USD) }\end{array}$ &.. & $\begin{array}{c}- \\
2205\end{array}$ & $\begin{array}{c}- \\
1602 \\
40\end{array}$ & 23.90 \\
\hline $\begin{array}{l}\text { Percentage } \\
\text { PSE (\%) }\end{array}$ & .. & 2.7 & 14.9 & & $\begin{array}{l}\text { Percentage } \\
\text { CSE }(\%)\end{array}$ & .. & -0.9 & -11.3 & \\
\hline $\begin{array}{l}\text { Producer NPC } \\
\text { (coeff.) }\end{array}$ & .. & 1.00 & 1.13 & & $\begin{array}{c}\text { Consumer NPC } \\
\text { (coeff.) }\end{array}$ & .. & 1.01 & 1.14 & \\
\hline \multicolumn{4}{|c|}{ Indonesia $^{1,6}$} & \multicolumn{6}{|c|}{ Indonesia $^{1,6}$} \\
\hline $\begin{array}{l}\text { PSE (million } \\
\text { USD) }\end{array}$ &.. & 1330 & $\begin{array}{c}3166 \\
5\end{array}$ & 17.18 & $\begin{array}{l}\text { CSE (million } \\
\text { USD) }\end{array}$ & .. & $\begin{array}{c}- \\
1162\end{array}$ & $\begin{array}{c}- \\
3254 \\
8 \\
\end{array}$ & 18.13 \\
\hline $\begin{array}{l}\text { Percentage } \\
\text { PSE (\%) }\end{array}$ & .. & 3.5 & 24.9 & & $\begin{array}{l}\text { Percentage } \\
\text { CSE }(\%)\end{array}$ & .. & -3.2 & -30.2 & \\
\hline $\begin{array}{c}\text { Producer NPC } \\
\text { (coeff.) }\end{array}$ & .. & 1.03 & 1.32 & & $\begin{array}{c}\text { Consumer NPC } \\
\text { (coeff.) }\end{array}$ & .. & 1.03 & 1.47 & \\
\hline \multicolumn{4}{|c|}{ Kazakhstan $^{1}$} & \multicolumn{6}{|c|}{ Kazakhstan ${ }^{1}$} \\
\hline $\begin{array}{l}\text { PSE (million } \\
\text { USD) }\end{array}$ &.. & 274 & 893 & 6.09 & $\begin{array}{l}\text { CSE (million } \\
\text { USD) }\end{array}$ & .. & -356 & 233 & $\begin{array}{c}- \\
198.0 \\
0\end{array}$ \\
\hline $\begin{array}{l}\text { Percentage } \\
\text { PSE (\%) }\end{array}$ & .. & 6.7 & 5.0 & & $\begin{array}{l}\text { Percentage } \\
\text { CSE }(\%)\end{array}$ & .. & -9.7 & 3.9 & \\
\hline $\begin{array}{c}\text { Producer NPC } \\
\text { (coeff.) }\end{array}$ & .. & 1.06 & 0.97 & & $\begin{array}{c}\text { Consumer NPC } \\
\text { (coeff.) }\end{array}$ & .. & 1.10 & 0.98 & \\
\hline \multicolumn{4}{|c|}{ Philippines $^{7}$} & \multicolumn{6}{|c|}{ Philippines $^{7}$} \\
\hline $\begin{array}{l}\text { PSE (million } \\
\text { USD) }\end{array}$ & .. & 2011 & 7593 & 6.87 & $\begin{array}{l}\text { CSE (million } \\
\text { USD) }\end{array}$ & .. & $\begin{array}{c}- \\
2109\end{array}$ & $\begin{array}{c}- \\
7940\end{array}$ & 6.85 \\
\hline $\begin{array}{l}\text { Percentage } \\
\text { PSE (\%) }\end{array}$ & .. & 20.5 & 24.5 & & $\begin{array}{l}\text { Percentage } \\
\text { CSE }(\%)\end{array}$ & .. & -21.2 & -25.0 & \\
\hline $\begin{array}{c}\text { Producer NPC } \\
\text { (coeff.) }\end{array}$ & .. & 1.29 & 1.33 & & $\begin{array}{c}\text { Consumer NPC } \\
\text { (coeff.) }\end{array}$ & .. & 1.30 & 1.35 & \\
\hline \multicolumn{4}{|c|}{ Viet $\mathrm{Nam}^{7}$} & \multicolumn{6}{|c|}{ Viet $\mathrm{Nam}^{7}$} \\
\hline $\begin{array}{l}\text { PSE (million } \\
\text { USD) }\end{array}$ &.. & 518 & -992 & $\begin{array}{c}- \\
203.1 \\
4\end{array}$ & $\begin{array}{l}\text { CSE (million } \\
\text { USD) }\end{array}$ & .. & -605 & $\begin{array}{c}- \\
1746\end{array}$ & 5.44 \\
\hline $\begin{array}{l}\text { Percentage } \\
\text { PSE }(\%)\end{array}$ & .. & 5.9 & -2.5 & & $\begin{array}{l}\text { Percentage } \\
\text { CSE }(\%)\end{array}$ & .. & -8.0 & -4.9 & \\
\hline $\begin{array}{c}\text { Producer NPC } \\
\text { (coeff.) }\end{array}$ & .. & 1.07 & 0.99 & & $\begin{array}{c}\text { Consumer NPC } \\
\text { (coeff.) }\end{array}$ & .. & 1.09 & 1.07 & \\
\hline \multicolumn{4}{|c|}{ EUROPE } & \multicolumn{6}{|c|}{ EUROPE } \\
\hline \multicolumn{4}{|c|}{ European Union $^{2}$} & \multicolumn{6}{|c|}{ European Union $^{2}$} \\
\hline PSE (million & 973 & 1169 & 1018 & -0.69 & CSE (million & - & - & - & -4.86 \\
\hline USD) & 79 & 53 & 19 & & USD) & $\begin{array}{c}7247 \\
5\end{array}$ & $\begin{array}{c}5835 \\
1\end{array}$ & $\begin{array}{c}2156 \\
3\end{array}$ & \\
\hline $\begin{array}{l}\text { Percentage } \\
\text { PSE }(\%)\end{array}$ & 39.2 & 33.8 & 19.6 & & $\begin{array}{l}\text { Percentage } \\
\text { CSE }(\%)\end{array}$ & -35.7 & -20.8 & -4.7 & \\
\hline $\begin{array}{c}\text { Producer NPC } \\
\text { (coeff.) }\end{array}$ & 1.69 & 1.33 & 1.05 & & $\begin{array}{c}\text { Consumer NPC } \\
\text { (coeff.) }\end{array}$ & 1.69 & 1.30 & 1.05 & \\
\hline \multicolumn{4}{|c|}{ Iceland } & \multicolumn{6}{|c|}{ Iceland } \\
\hline $\begin{array}{l}\text { PSE (million } \\
\text { USD) }\end{array}$ & 193 & 131 & 204 & 2.24 & $\begin{array}{l}\text { CSE (million } \\
\text { USD) }\end{array}$ & -112 & -59 & -103 & 2.83 \\
\hline $\begin{array}{c}\text { Percentage } \\
\text { PSE (\%) }\end{array}$ & 77.2 & 60.4 & 55.5 & & $\begin{array}{l}\text { Percentage } \\
\text { CSE }(\%)\end{array}$ & -70.4 & -42.9 & -43.2 & \\
\hline $\begin{array}{c}\text { Producer NPC } \\
\text { (coeff.) }\end{array}$ & 4.16 & 2.32 & 1.98 & & $\begin{array}{c}\text { Consumer NPC } \\
\text { (coeff.) }\end{array}$ & 4.38 & 1.82 & 1.77 & \\
\hline \multicolumn{4}{|c|}{ Norway } & \multicolumn{6}{|c|}{ Norway } \\
\hline $\begin{array}{l}\text { PSE (million } \\
\text { USD) }\end{array}$ & $\begin{array}{c}280 \\
1\end{array}$ & 2910 & 3456 & 0.86 & $\begin{array}{l}\text { CSE (million } \\
\text { USD) }\end{array}$ & - & $\begin{array}{c}- \\
1261\end{array}$ & - & 1.54 \\
\hline
\end{tabular}




\begin{tabular}{|c|c|c|c|c|c|c|c|c|c|}
\hline $\begin{array}{l}\text { Percentage } \\
\text { PSE (\%) }\end{array}$ & 70.4 & 66.3 & 59.7 & & $\begin{array}{l}\text { Percentage } \\
\text { CSE }(\%)\end{array}$ & -55.8 & -47.4 & -42.5 & \\
\hline $\begin{array}{c}\text { Producer NPC } \\
\text { (coeff.) }\end{array}$ & 4.06 & 2.50 & 1.91 & & $\begin{array}{c}\text { Consumer NPC } \\
\text { (coeff.) }\end{array}$ & 3.22 & 2.12 & 1.83 & \\
\hline \multicolumn{4}{|c|}{ Switzerland } & \multicolumn{6}{|c|}{ Switzerland } \\
\hline $\begin{array}{l}\text { PSE (million } \\
\text { USD) }\end{array}$ & $\begin{array}{c}673 \\
9\end{array}$ & 7175 & 7272 & 0.07 & $\begin{array}{l}\text { CSE (million } \\
\text { USD) }\end{array}$ & $\begin{array}{c}- \\
6459\end{array}$ & $\begin{array}{c}- \\
5763\end{array}$ & $\begin{array}{c}- \\
4172\end{array}$ & -1.60 \\
\hline $\begin{array}{l}\text { Percentage } \\
\text { PSE }(\%)\end{array}$ & 75.6 & 65.1 & 57.7 & & $\begin{array}{l}\text { Percentage } \\
\text { CSE (\%) }\end{array}$ & -74.3 & -60.8 & -40.4 & \\
\hline $\begin{array}{c}\text { Producer NPC } \\
\text { (coeff.) }\end{array}$ & 4.21 & 2.69 & 1.68 & & $\begin{array}{c}\text { Consumer NPC } \\
\text { (coeff.) }\end{array}$ & 4.49 & 2.91 & 1.69 & \\
\hline \multicolumn{4}{|c|}{ Russia $^{1}$} & \multicolumn{6}{|c|}{ Russia $^{1}$} \\
\hline $\begin{array}{l}\text { PSE (million } \\
\text { USD) }\end{array}$ & .. & 6522 & $\begin{array}{c}1126 \\
2\end{array}$ & 2.77 & $\begin{array}{l}\text { CSE (million } \\
\text { USD) }\end{array}$ & .. & $\begin{array}{c}- \\
1561\end{array}$ & $\begin{array}{c}- \\
9720\end{array}$ & 9.58 \\
\hline $\begin{array}{l}\text { Percentage } \\
\text { PSE (\%) }\end{array}$ & .. & 19.6 & 13.9 & & $\begin{array}{l}\text { Percentage } \\
\text { CSE (\%) }\end{array}$ & .. & -5.4 & -12.0 & \\
\hline $\begin{array}{l}\text { Producer NPC } \\
\text { (coeff.) }\end{array}$ & .. & 1.07 & 1.10 & & $\begin{array}{c}\text { Consumer NPC } \\
\text { (coeff.) }\end{array}$ & .. & 1.05 & 1.14 & \\
\hline \multicolumn{4}{|c|}{ Ukraine $^{1}$} & \multicolumn{6}{|c|}{ Ukraine $^{1}$} \\
\hline $\begin{array}{l}\text { PSE (million } \\
\text { USD) }\end{array}$ & .. & $\begin{array}{c}- \\
1169 \\
\end{array}$ & $\begin{array}{c}- \\
2552 \\
\end{array}$ & 3.98 & $\begin{array}{l}\text { CSE (million } \\
\text { USD) }\end{array}$ & .. & 1950 & 2302 & 0.83 \\
\hline $\begin{array}{l}\text { Percentage } \\
\text { PSE (\%) }\end{array}$ & .. & -7.5 & -8.6 & & $\begin{array}{l}\text { Percentage } \\
\text { CSE }(\%)\end{array}$ & .. & 19.6 & 13.6 & \\
\hline $\begin{array}{l}\text { Producer NPC } \\
\text { (coeff.) }\end{array}$ & .. & 0.87 & 0.88 & & $\begin{array}{c}\text { Consumer NPC } \\
\text { (coeff.) }\end{array}$ & .. & 0.82 & 0.86 & \\
\hline \multicolumn{4}{|c|}{ NORTH AMERICA } & \multicolumn{6}{|c|}{ NORTH AMERICA } \\
\hline \multicolumn{4}{|c|}{ Canada } & \multicolumn{6}{|c|}{ Canada } \\
\hline $\begin{array}{l}\text { PSE (million } \\
\text { USD) }\end{array}$ & $\begin{array}{c}613 \\
6\end{array}$ & 3524 & 4424 & 1.14 & $\begin{array}{l}\text { CSE (million } \\
\text { USD) }\end{array}$ & $\begin{array}{c}- \\
2860\end{array}$ & $\begin{array}{c}- \\
1758\end{array}$ & $\begin{array}{c}- \\
2968\end{array}$ & 2.65 \\
\hline $\begin{array}{c}\text { Percentage } \\
\text { PSE (\%) }\end{array}$ & 36.1 & 16.1 & 9.3 & & $\begin{array}{c}\text { Percentage } \\
\text { CSE }(\%)\end{array}$ & -22.7 & -11.2 & -10.0 & \\
\hline $\begin{array}{l}\text { Producer NPC } \\
\text { (coeff.) }\end{array}$ & 1.38 & 1.10 & 1.06 & & $\begin{array}{c}\text { Consumer NPC } \\
\text { (coeff.) }\end{array}$ & 1.33 & 1.13 & 1.11 & \\
\hline \multicolumn{4}{|c|}{ United States } & \multicolumn{6}{|c|}{ United States } \\
\hline $\begin{array}{l}\text { PSE (million } \\
\text { USD) }\end{array}$ & $\begin{array}{c}353 \\
37\end{array}$ & $\begin{array}{c}2561 \\
7\end{array}$ & $\begin{array}{c}3841 \\
3\end{array}$ & 2.05 & $\begin{array}{l}\text { CSE (million } \\
\text { USD) }\end{array}$ & - & 6157 & $\begin{array}{c}2964 \\
8\end{array}$ & 8.18 \\
\hline $\begin{array}{l}\text { Percentage } \\
\text { PSE (\%) }\end{array}$ & 21.2 & 11.9 & 9.5 & & $\begin{array}{l}\text { Percentage } \\
\text { CSE }(\%)\end{array}$ & -2.4 & 4.3 & 11.6 & \\
\hline $\begin{array}{l}\text { Producer NPC } \\
\text { (coeff.) }\end{array}$ & 1.12 & 1.06 & 1.03 & & $\begin{array}{c}\text { Consumer NPC } \\
\text { (coeff.) }\end{array}$ & 1.12 & 1.08 & 1.04 & \\
\hline \multicolumn{4}{|c|}{ Mexico $^{4}$} & \multicolumn{6}{|c|}{ Mexico $^{4}$} \\
\hline $\begin{array}{l}\text { PSE (million } \\
\text { USD) }\end{array}$ & $\begin{array}{c}843 \\
7\end{array}$ & 1645 & 5694 & 6.41 & $\begin{array}{l}\text { CSE (million } \\
\text { USD) }\end{array}$ & $\begin{array}{c}- \\
6363\end{array}$ & 234 & -339 & $\begin{array}{c}- \\
201.7 \\
8\end{array}$ \\
\hline $\begin{array}{l}\text { Percentage } \\
\text { PSE }(\%)\end{array}$ & 28.5 & 6.9 & 9.8 & & $\begin{array}{l}\text { Percentage } \\
\text { CSE }(\%)\end{array}$ & -24.5 & 0.4 & -0.6 & \\
\hline $\begin{array}{l}\text { Producer NPC } \\
\text { (coeff.) }\end{array}$ & 1.34 & 1.01 & 1.02 & & $\begin{array}{c}\text { Consumer NPC } \\
\text { (coeff.) }\end{array}$ & 1.38 & 1.02 & 1.02 & \\
\hline \multicolumn{4}{|c|}{ Costa Rica $^{1}$} & \multicolumn{6}{|c|}{ Costa Rica $^{1}$} \\
\hline $\begin{array}{l}\text { PSE (million } \\
\text { USD) }\end{array}$ & .. & 88 & 501 & 9.09 & $\begin{array}{l}\text { CSE (million } \\
\text { USD) }\end{array}$ &.. & -87 & -467 & 8.77 \\
\hline $\begin{array}{l}\text { Percentage } \\
\text { PSE }(\%)\end{array}$ & .. & 3.9 & 10.0 & & $\begin{array}{l}\text { Percentage } \\
\text { CSE }(\%)\end{array}$ & .. & -8.0 & -17.8 & \\
\hline $\begin{array}{c}\text { Producer NPC } \\
\text { (coeff.) }\end{array}$ & .. & 1.04 & 1.11 & & $\begin{array}{c}\text { Consumer NPC } \\
\text { (coeff.) }\end{array}$ & .. & 1.09 & 1.22 & \\
\hline \multirow{2}{*}{\multicolumn{4}{|c|}{$\begin{array}{c}\text { SOUTH AMERICA } \\
\text { Chile }^{1}\end{array}$}} & \multicolumn{6}{|c|}{ SOUTH AMERICA } \\
\hline & & & & & & Chile $^{1}$ & & & \\
\hline $\begin{array}{l}\text { PSE (million } \\
\text { USD) }\end{array}$ & .. & 390 & 393 & 0.04 & $\begin{array}{l}\text { CSE (million } \\
\text { USD) }\end{array}$ &.. & -392 & -32 & -11.77 \\
\hline $\begin{array}{l}\text { Percentage } \\
\text { PSE (\%) }\end{array}$ & .. & 7.5 & 3.0 & & $\begin{array}{c}\text { Percentage } \\
\text { CSE }(\%)\end{array}$ & .. & -7.6 & -0.3 & \\
\hline
\end{tabular}




\begin{tabular}{|c|c|c|c|c|c|c|c|c|c|}
\hline $\begin{array}{c}\text { Producer NPC } \\
\text { (coeff.) }\end{array}$ & .. & 1.07 & 1.00 & & $\begin{array}{l}\text { Consumer NPC } \\
\text { (coeff.) }\end{array}$ &. & 1.08 & 1.00 & \\
\hline \multicolumn{4}{|c|}{ Brazil $^{1}$} & \multicolumn{6}{|c|}{ Brazil $^{1}$} \\
\hline $\begin{array}{l}\text { PSE (million } \\
\text { USD) }\end{array}$ & .. & $\begin{array}{c}- \\
6826\end{array}$ & 6221 & $\begin{array}{c}- \\
199.5 \\
6\end{array}$ & $\begin{array}{l}\text { CSE (million } \\
\text { USD) }\end{array}$ & .. & 6442 & -166 & $\begin{array}{c}- \\
184.0 \\
1\end{array}$ \\
\hline $\begin{array}{l}\text { Percentage } \\
\text { PSE (\%) }\end{array}$ & .. & -14.4 & 3.8 & & $\begin{array}{l}\text { Percentage } \\
\text { CSE (\%) }\end{array}$ & .. & 12.3 & -0.3 & \\
\hline $\begin{array}{l}\text { Producer NPC } \\
\text { (coeff.) }\end{array}$ & .. & 0.82 & 1.01 & & $\begin{array}{l}\text { Consumer NPC } \\
\text { (coeff.) }\end{array}$ & .. & 0.89 & 1.02 & \\
\hline \multicolumn{4}{|c|}{ Colombia $^{1}$} & \multicolumn{6}{|c|}{ Colombia $^{1}$} \\
\hline $\begin{array}{l}\text { PSE (million } \\
\text { USD) }\end{array}$ & .. & 3451 & 4112 & 0.88 & $\begin{array}{l}\text { CSE (million } \\
\text { USD) }\end{array}$ &.. & $\begin{array}{c}- \\
3207\end{array}$ & $\begin{array}{c}- \\
3392\end{array}$ & 0.28 \\
\hline $\begin{array}{l}\text { Percentage } \\
\text { PSE }(\%)\end{array}$ & .. & 24.0 & 15.5 & & $\begin{array}{l}\text { Percentage } \\
\text { CSE }(\%)\end{array}$ & .. & -30.3 & -15.4 & \\
\hline $\begin{array}{l}\text { Producer NPC } \\
\text { (coeff.) }\end{array}$ & .. & 1.30 & 1.13 & & $\begin{array}{l}\text { Consumer NPC } \\
\text { (coeff.) }\end{array}$ & .. & 1.44 & 1.18 & \\
\hline \multicolumn{4}{|c|}{ OECD $^{5}$} & \multicolumn{6}{|c|}{ OECD $^{5}$} \\
\hline $\begin{array}{l}\text { PSE (million } \\
\text { USD) }\end{array}$ & $\begin{array}{l}217 \\
205\end{array}$ & $\begin{array}{c}2505 \\
39\end{array}$ & $\begin{array}{c}2348 \\
29\end{array}$ & -0.32 & $\begin{array}{l}\text { CSE (million } \\
\text { USD) }\end{array}$ & $\begin{array}{c}- \\
1618 \\
26\end{array}$ & $\begin{array}{c}- \\
1677 \\
35\end{array}$ & $\begin{array}{c}- \\
7886 \\
3\end{array}$ & -3.70 \\
\hline $\begin{array}{l}\text { Percentage } \\
\text { PSE (\%) }\end{array}$ & 36.5 & 30.4 & 18.2 & & $\begin{array}{l}\text { Percentage } \\
\text { CSE (\%) }\end{array}$ & -33.2 & -24.2 & -7.6 & \\
\hline $\begin{array}{c}\text { Producer NPC } \\
\text { (coeff.) }\end{array}$ & 1.51 & 1.31 & 1.10 & & $\begin{array}{l}\text { Consumer NPC } \\
\text { (coeff.) }\end{array}$ & 1.59 & 1.37 & 1.13 & \\
\hline
\end{tabular}

Note: p: provisional. NPC: Nominal Protection Coefficient. NAC: Nominal Assistance

Coefficient. 1. Data are presented from 1995 onwards. 2. EU12 for 1986-88; EU15 for 1995-97; and EU28 from 2014 when available. 3. The statistical data for Israel are supplied by and under the responsibility of the relevant Israeli authorities. The use of such data by the

OECD is without prejudice to the status of the Golan Heights, East Jerusalem and Israeli

settlements in the West Bank under the terms of international law. 4. For Mexico, the period 1986-88 is replaced by 1991-93. 5. OECD EU countries are included individually in the OECD total for all years prior to their accession to the EU except Latvia, for which data is not available. Slovenia is only included from 1992. The OECD total does not include the non-OECD EU member states. 6. For Indonesia, the period 2014-16 is replaced by 201315. 7. For Philippines and Viet Nam, the period 1995-97 is replaced by 2000-02. Data are presented from 2000 onwards.

Source: OECD (2017), "Producer and Consumer Support Estimates”, OECD Agriculture statistics (database).

The Producer support estimates percentages of the various countries are given in the Figure 1. The trend line is drawn with the base-line of 198688 . 


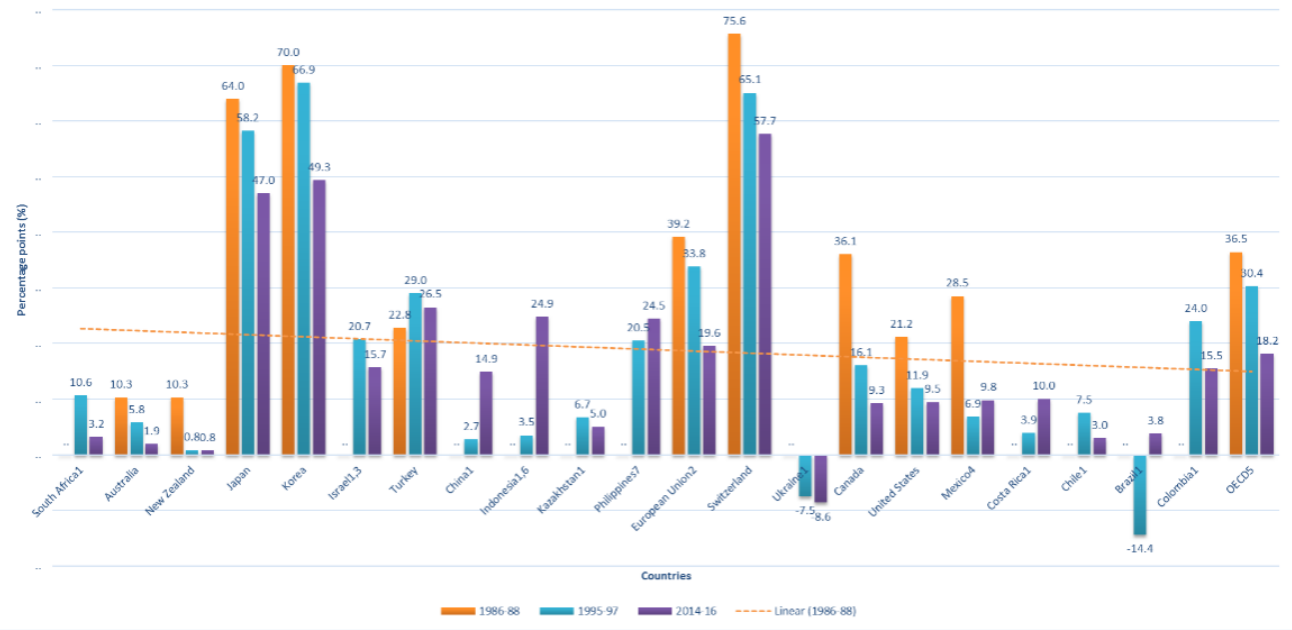

The Contribution of Budgetary Payments to change in Producer Support Estimate by country, 2015 to 2016 is given in Table 12. Most of the developed economies such as Australia, New Zealand, Japan the EU, Iceland, Switzerland, Norway and Canada; some of the developing economies such as Turkey, Vietnam, Russia and Brazil; and the OECD Countries have positive change towards the contribution of budgetary Payments to change in Producer Support Estimate by country, 2015 to 2016.

Table 12. Contribution of Budgetary Payments to change in Producer Support Estimate by country, 2015 to 2016

\begin{tabular}{|c|c|c|c|c|c|c|c|c|c|}
\hline \multirow[b]{3}{*}{ Country } & $\begin{array}{l}\text { Producer } \\
\text { Support }\end{array}$ & \multicolumn{8}{|c|}{$\%$ change in PSE, contribution of Budgetary Payments, all other variables held constant } \\
\hline & \multirow[b]{2}{*}{$\begin{array}{c}\% \\
\text { change }\end{array}$} & \multirow[b]{2}{*}{ Total } & \multicolumn{7}{|c|}{ Payments based on: } \\
\hline & & & Output & $\begin{array}{l}\text { Input } \\
\text { use }\end{array}$ & $\begin{array}{c}\text { Current } \\
\text { A/An/R/I, } \\
\text { production } \\
\text { required }\end{array}$ & $\begin{array}{c}\text { Non- } \\
\text { current } \\
\text { A/An/R/I, } \\
\text { production } \\
\text { required }\end{array}$ & $\begin{array}{c}\text { Non- } \\
\text { current } \\
\text { A/An/R/I, } \\
\text { production } \\
\text { not } \\
\text { required }\end{array}$ & $\begin{array}{l}\text { Non- } \\
\text { commodity } \\
\text { criteria }\end{array}$ & $\begin{array}{c}\text { Miscellaneous } \\
\text { payments }\end{array}$ \\
\hline \multicolumn{10}{|c|}{ AFRICA } \\
\hline South Africa & -44.1 & -0.6 & 0.0 & 1.6 & -2.2 & 0.0 & 0.0 & 0.0 & 0.0 \\
\hline \multicolumn{10}{|c|}{ AUSTRALASIAN } \\
\hline Australia & 14.7 & 14.7 & 0.0 & 7.8 & 3.3 & 0.0 & 4.4 & 0.0 & -0.9 \\
\hline New Zealand & 49.7 & 3.6 & 0.0 & 2.3 & 1.3 & 0.0 & 0.0 & 0.0 & 0.0 \\
\hline \multicolumn{10}{|c|}{ ASIA } \\
\hline Israel (2) & -3.3 & -0.4 & -0.1 & -0.1 & -0.1 & 0.0 & -0.0 & 0.0 & 0.0 \\
\hline Japan & 6.4 & 0.6 & -0.3 & -0.4 & 0.9 & 0.0 & 0.4 & 0.0 & 0.0 \\
\hline Korea & -1.4 & 2.6 & 0.0 & 0.2 & 2.4 & 0.0 & -0.0 & 0.0 & 0.0 \\
\hline Turkey & 10.2 & 1.9 & 0.8 & 0.2 & 0.9 & 0.0 & 0.0 & 0.0 & 0.0 \\
\hline China & -1.5 & -0.2 & 0.0 & -0.3 & 0.3 & 0.0 & -0.2 & 0.0 & -0.1 \\
\hline Viet Nam & 8.4 & 0.0 & 0.0 & 0.0 & 0.0 & 0.0 & 0.0 & 0.0 & 0.0 \\
\hline Kazakhstan & -136.2 & 7.8 & 2.6 & 8.2 & -3.4 & 0.0 & 0.0 & 0.4 & 0.0 \\
\hline Philippines & -16.7 & -0.8 & 0.0 & -0.9 & 0.1 & 0.0 & 0.0 & 0.0 & 0.0 \\
\hline
\end{tabular}




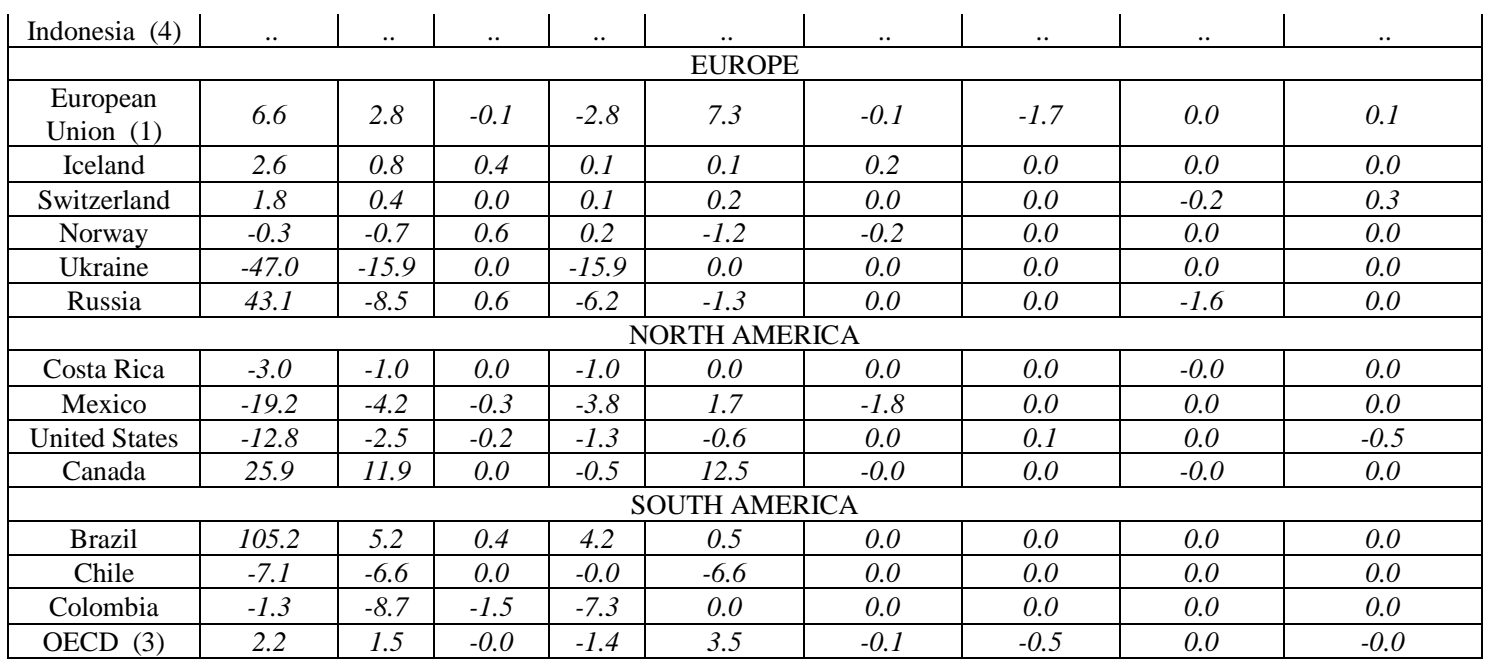

1. 28 member countries.

2. The statistical data for Israel are supplied by and under the responsibility of the relevant Israeli authorities. The use of such data by the OECD is without prejudice to the status of the Golan Heights, East Jerusalem and Israeli settlements in the West Bank under the terms of international law. 3. Average of $\%$ changes in PSE in OECD countries (in national currency) weighted by the shares of national PSEs within the PSE of the OECD of the previous year; not equivalent to the change in OECD PSE expressed in a common currency.

4. 2016 data are not available and hence no decomposition could be made.

Source: OECD (2017), "Producer and Consumer Support Estimates", OECD Agriculture statistics (database).

\section{Conclusion}

International political economy studies problems that arise from or are affected by the interaction of international politics, international economics, and different social systemsThe study focused on the incentives and strategies of politicians, economists, agency officials, and environmental advocates and how this web of interactions affects agricultural and food policies, farmers, consumer, welfare and economic growth. It was found that most of the developed countries are capitalistic and developing countries are socialistic. Only few countries which are communist. But majority of the countries in the world are mixed economies in operation. These type of economies play an important role in resource allocation and protection of agriculture.

The real GDP (\%) is either increasing or follows a mixed trend in case of developed countries in contrast to the developing countries decreasing trend. However, the decreasing trend of developing countries real GDP (\%) will not enable them to allocate more on agriculture. All the G7 advanced 
economies, 30 emerging and developing Asian economies, only 4 countries (China, India, Indonesia and Thailand), among the Middle Eastern countries, North Africa, Afghanistan and Pakistan, the UAE, Saudi Arabia and Iran are major economies with at least $0.5 \%$ of Global GDP. And in 45 Sub-Saharan African Countries only Nigeria has at least $0.5 \%$ of Global GDP. It shows that Africa is the highest backward continent in the world. Countries which have less than $0.5 \%$ of Global GDP has a disadvantage in budget allocation to agriculture. Nigeria has the maximum (17.8\%) share of GDP to Agriculture, followed by India (17.2\%). The UK (0.7\%), Belgium (0.7\%), Germany $(0.8 \%)$ and the UAE $(0.8 \%)$ have the least share of agriculture sector contribution to their GDP's. And the economies of the US and France have almost service sector share of nearly $80 \%$.

Government investments may be assigned priorities according to their cost-benefit ratios. High dependence on agriculture is observed in most of the developing countries and the high income economies are focusing more on $(>50 \%)$ service sector. Saudi Arabia and the UAE has high industry sector share ( $>50 \%)$ which is due to their exploration of oil and petroleum reserves. The more dependence on agriculture will allow the politicians to exploit in the elections. The political economy of AOI indicates that the countries which have more than 1 will spend more budget in budget allocation towards agriculture. It was found that most of the countries AOI is less than 1, which depicts that, clearly agriculture globally is not on the priority list for the local central governments, except for South Korea and Switzerland, whose agriculture orientation index is greater than 1(1.96 and 5.08 respectively).

International institutions Governments like World Bank has been giving low to medium preference to funding in Agriculture, Fishing and Forestry, among various sectors. This shows that poor treatment towards the agriculture sector. The study observed that Middle East and North African Countries are funded extremely low in comparison to other regions of the world by IDA and IBRD. This could be due to the political instability and terrorism, which hinders the growth of the regions. The sudden increase of funds to Argentina and decreased funding for the countries Nigeria, India, Mexico and Brazil was found.

The numerical targets established by the URAA are not followed in many WTO member countries which have comparative advantage. During the period 2000 to 2016, Russia, India, China and New Zealand are given more domestic support and Mexico, Chile, USA, Japan and OECD countries were given decreasing support to agricultural sector than compared to other WTO member countries. Among the Asian countries Korea, China, Indonesia and Vietnam support the consumers over the producers. Whereas, Kazakhstan, Turkey, Israel and Japan supports the producers over the consumers. In the European nations, Iceland, Norway and Russia support the consumers over the 
producers in contrast to the Switzerland's and Ukraine's way of support. In North and South America only the large economies such as Canada, the USA and Brazil support the consumers over the producers.

The political economy of protecting producer and consumer depends upon their share of votes in elections. Capitalistic countries protect more producer compared to consumer, contrastingly, socialist or mixed economies protect more consumer because of political benefits in elections. Globally, political and economic systems, international governments like World Bank, Trade organizations and WTO's attitude towards agriculture is poor. Hence, agriculture must be brought on the global political agenda for the sustainable food security, economic development and to achieve Millennium Development Goals (MDG's). The protection of producers and consumers is being based on the political will of the governments. The study suggests that, economic minded politicians and political minded economists who has knowledge of social, political and economic systems are required in efficient economic system of agriculture.

Acknowledgements: SERB, Ministry of Science and Technology, Government of India support for funding this study.

\section{References:}

1. Aghion, Philippe, Alberto Alesina, and Francesco Trebbi. 2004. Endogenous Political Institutions. Quarterly Journal of Economics 119(2): 565-612.

2. Anania, Giovanni, Mary E. Bohman, Colin A. Carter, and Alex F. McCalla. 2004. Agricultural Policy Reform and the WTO: Where Are We Heading? London: Edward Elgar.

3. Bagwell, Kyle, and Robert W. Staiger. 2002. The Economics of the World Trading System. Cambridge, MA: MIT Press.

4. Banerji, Arup, and Hafez Ghanem. 1997. Does the Type of Political Regime Matter for Trade and Labor Market Policies? World Bank Economic Review 11(1): 171-194.

5. Blanchard, Emily, and Gerald Willmann. 2007. Political Statis or Protectionist Rut? Policy Mechanisms for Trade Reform in a Democracy. CESIFO Working Paper No. 2070.

6. Buchanan, James M., and Gordon Tullock. 1962. The Calculus of Consent. AnnArbor: University of Michigan Press.

7. Calibre (2012) FAO OECD Agricultural Outlook: Looming foodcrisis. (http://thecalibre.in).

8. Damodar NG and Sangeetha (2007), 'Basic Econometrics', Tata McGraw Hill Publishing Company Ltd, New Delhi. 2007, pp: 182183. 
9. Dalkey N C and Helmer O (1963) An experimental application of the Delphi method to the use of experts. Management Science, 9 (3), 458467.

10. Dastagiri MB (1998) World food production research. Out- look on Agriculture, 27 (2).

11. Dastagiri MB (2017) "Global Agriculture: Vision and Approaches" European Scientific Journal. France, 13(21):312-325.

12. Dutt, Pushan, and Devashish Mitra. 2005. Political Ideology and Endogenous Trade Policy: An Empirical Investigation. Review of Economics and Statistics 87(1): 59-72.

13. Dutt, Pushan, and Devashish Mitra. 2007. Political Economy of Agricultural Protection: A Framework. Paper presented at the World Bank Workshop on The Political Economy of Agricultural Distortions, Portland, OR.

14. FAO (2012) Investing in agriculture for a better future. The State of Food and Agriculture 2012, FAO Publication. http://www.fao.org/docrep/017/i3028e/i3028e.pdf.

15. IFAD (2011) Responding to 'Land Grabbing' and promoting responsible investment in agriculture, Occasional Paper Series 2.https://www.ifad.org/documents/10180/c7d51222-fbf3-41d1-b72c2df3912f9b41.

16. IFPRI (2011) Global food security report 2011. International Food Policy Research Institute,

17. http://groupedebruges.eu/sites/default/files/publications/downloads/gl obal_food_policy_report_2011_ifpri-_full_version_.pdf.

18. Iowa Public Television http://www.iptv.org/mtom/classroom/module/14002/role-ofgovernment-in-agriculture accessed on 21/12/2017.

19. Johan F.M. Swinnen and Kym Anderson. 2010. External Changes, Crises and Discontinuous Policy Change. The Political Economy of Agricultural and Food Policies.

20. Masters, William A., and Margaret S. McMillan. 2000. Understanding the Political Economy of Agriculture in the Tropics. American Journal of Agricultural Economics 82(3), August, 738-42.

21. McMillan, Margaret. 2001. Why Kill the Golden Goose? A Political Economy Model of Export Taxation. Review of Economics and Statistics 83(1): 170-84. The Political Economy of Agricultural and Food Policies

22. Milner, Helen V., and Keiko Kubota. 2005. Why the Move to Free Trade? Democracy and Trade Policy in the Developing Countries. International Organization 59(1): 107-143. 
23. Mrityunjay M J and Singh R B (2008) Land Use: reflection on spatial informatics agriculture and development, Concepts Publishing Company, New Delhi-11009

24. National Research Council (US) Steering Committee on Valuing Health Risks, Costs, and Benefits for Environmental Decisions; Hammond PB, Coppock R, editors. Valuing Health Risks, Costs, and Benefits for Environmental Decision Making: Report of a Conference. Washington (DC): National Academies Press (US); 1990. 3, The Politics Of Benefit-Cost Analysis. Available from: https://www.ncbi.nlm.nih.gov/books/NBK235528/

25. Olper, Alessandro, and Valentina Raimondi. In press 2009. Constitutional Rules and Agricultural Protection. In The Political Economy of Distortions to Agriculture, ed. Kym Anderson, Washington, DC: World Bank.

26. Persson, Torsten, and Guido E. Tabellini. 2002. "Do Constitutions cause large Governments? Quasi-Experimental evidence". European Economic review 46, 908-918.

27. Persson, Torsten, and Guido E. Tabellini. 2003. The Economic Effects of Constitutions: What Do the Data Say? Cambridge, MA: MIT Press.

28. Prendergast, Canice. 2007. The Motivation and Bias of Bureaucrats. American Economic Review 97(1): 180-196.

29. Rhoads, Steven 1985. The Economist's View of the World' Government, Markets, and Public Policy. Cambridge: Cambridge University Press.

30. Rozelle, Scott, and Johan F.M. Swinnen. 2009. Why Did the Communist Party Reform in China, but not in the Soviet Union? The Political Economy of Agricultural Transition. China Economic Review 20(2): 275-287.

31. Schultze, Charles 1977. The Public Use of Private Interest. Washington, D.C.: Brookings Institution.

32. Subramaniam G (2012) The looming global food crisis and the way out. The Hindu, 13August. http://www.thehindu.com/news/national/the-looming-globalfoodcrisis-and-the-way-out/article3759335.ece

33. Swinnen, Johan F. M., The Political Economy of Agricultural and Food Policies: Recent Contributions, New Insights, and Areas for Further Research (Spring 2010). Applied Economic Perspectives and Policy, Vol. 32, Issue 1, pp. 33-58, 2010. Available at SSRN: https://ssrn.com/abstract=1556179 or http://dx.doi.org/ppp012

34. Swinnen, Johan F. M. Forthcoming 2009. Impacts of Ideology, Inequality and Democracy on Agricultural Distortion Patterns. In The 
Political Economy of Distortions to Agriculture, ed. Kym Anderson. Washington, DC: World Bank.

35. Swinnen, Johan F.M., Anurag N. Banerjee, and Harry de Gorter. 2001. Economic Development, Institutional Change, and the Political Economy of Agricultural Protection: An Econometric Study of Belgium since the 19th Century. Agricultural Economics 26(1): 2543.

36. Valentin Z (2011) Food Security and the EU's Common Agricultural Policy: Facts Against Fears, ECIPE working paper No. 01/2011, European Centre for International Political Economy.

37. World Bank (2011) Rising global interest in farmland: can it yieldsustainable and equitable benefits? WB Report, 2011.https://siteresources.worldbank.org/DEC/Resources/RisingGlobal-Interest-in-Farmland.pdf.

38. World Watch Institute (2004) World Watch Magazine. September/October 2004, 17(5). 


\section{APPENDIX I}

Countries and their economies

\begin{tabular}{|c|c|c|}
\hline $\begin{array}{l}\mathbf{N} \\
\mathbf{0 .}\end{array}$ & $\begin{array}{c}\text { Country/Eco } \\
\text { nomy }\end{array}$ & Features \\
\hline \multirow{3}{*}{1} & \multicolumn{2}{|r|}{ AFRICA } \\
\hline & Nigeria & $\begin{array}{c}\text { Anocracy, Aristocracy, Banana Republic, Common Wealth, } \\
\text { Democracy, Dictatorship, Emirate, Federal Republic, Kleptocracy, } \\
\text { Parliamentary Republic. }\end{array}$ \\
\hline & \multicolumn{2}{|r|}{ ASIA } \\
\hline 1 & Indonesia & $\begin{array}{l}\text { Asymmetrical Federation, Bureaucracy, Colony, Democracy, } \\
\text { Federal Republic, Kleptocracy, Parliamentary Republic, } \\
\text { Presidential Democracy, Republic, Unitary state. }\end{array}$ \\
\hline 2 & Iran & Authoritarian, Autocracy, Gerontocracy, Islamic Republic. \\
\hline 3 & Saudi Arabia & $\begin{array}{l}\text { Absolute Monarchy, Authoritarian, Autocracy, Emirate, } \\
\text { Kleptocracy, Monarchy, Unitary State, Welfare State. }\end{array}$ \\
\hline \multirow[t]{2}{*}{4} & Turkey & $\begin{array}{c}\text { Authoritarian, Parliamentary Democracy, Parliamentary Republic, } \\
\text { Republic, Unitary State. }\end{array}$ \\
\hline & \multicolumn{2}{|r|}{ EUROPE } \\
\hline 1 & Russia & $\begin{array}{c}\text { Anocracy, Asymmetrical Federation, Authoritarian, } \\
\text { Corporatocracy, Dictatorship, Elective Monarchy, Federalism, } \\
\text { Feudalism, Kleptocracy, Leninism, Marxism, Noocracy, Oligarchy, } \\
\text { Parliamentary Republic, Provisional Government, Republic, } \\
\text { Socialist Republic, Stratocracy, Technocracy. }\end{array}$ \\
\hline 2 & Poland & $\begin{array}{c}\text { Alliance, Authoritarian, Democracy, Parliamentary Democracy, } \\
\text { People's Republic, Unitary State. }\end{array}$ \\
\hline & \multicolumn{2}{|r|}{ SOUTH AMERICA } \\
\hline 1 & Colombia & Democracy, Federal Republic, Unitary State. \\
\hline 2 & Argentina & $\begin{array}{c}\text { Bureaucracy, Colony, Democracy, Dictatorship, Federal Republic, } \\
\text { Federalism, Liberal Democracy, Republic, Stratocracy. }\end{array}$ \\
\hline 3 & Venezuela & $\begin{array}{c}\text { Authoritarian, Despotism, Federal Republic, Federalism, Oligarchy, } \\
\text { Republic. }\end{array}$ \\
\hline 4 & Brazil & $\begin{array}{l}\text { Colony, Democracy, Federal Republic, Federalism, Liberal } \\
\text { Democracy, Parliamentary Republic, Republic. }\end{array}$ \\
\hline
\end{tabular}

